\title{
Sedimentary archives of climate and sea-level changes during the Holocene in the Rhône prodelta (NW Mediterranean Sea)
}

\author{
Anne-Sophie Fanget ${ }^{1}$, Maria-Angela Bassetti ${ }^{1}$, Christophe Fontanier ${ }^{2}$, Alina Tudryn ${ }^{3}$, and Serge Berné ${ }^{1,2}$ \\ ${ }^{1}$ Université de Perpignan Via Domitia, Centre de Formation et de Recherche sur les Environnements Méditerranéens \\ (CEFREM), UMR 5110-CNRS, 66860, Perpignan, France \\ ${ }^{2}$ IFREMER, Laboratoire Environnements Sédimentaires, BP70, 29280 Plouzané, France \\ ${ }^{3}$ GEOPS UMR 8148, Univ. Paris-Sud, CNRS, Université Paris-Saclay, Rue du Belvédère, Bât. 504-509, \\ 91405 Orsay, France
}

Correspondence to: Anne-Sophie Fanget (annesophie.fanget@univ-perp.fr)

Received: 29 May 2016 - Published in Clim. Past Discuss.: 27 June 2016

Revised: 31 October 2016 - Accepted: 7 November 2016 - Published: 6 December 2016

\begin{abstract}
A $7.38 \mathrm{~m}$ long sediment core was collected from the eastern section of the Rhône prodelta (NW Mediterranean) at $67 \mathrm{~m}$ water depth. A multi-proxy study (including sedimentary facies, benthic foraminifera, ostracods, and clay mineralogy) provides a multi-decadal to century-scale record of climate and sea-level changes during the Holocene. The early Holocene is marked by alternative silt and clay layers interpreted as distal tempestites deposited in a context of rising sea level. This interval contains shallow infra-littoral benthic meiofauna (e.g., Pontocythere elongata, Elphidium spp., Quinqueloculina lata) and formed between ca. 20 and $50 \mathrm{~m}$ water depth. The middle Holocene (ca. 8.3 to $4.5 \mathrm{ka} \mathrm{cal}$. BP) is characterized, at the core site, by a period of sediment starvation (accumulation rate of ca. $0.01 \mathrm{~cm} \mathrm{yr}^{-1}$ ) resulting from the maximum landward shift of the shoreline and the Rhône outlet(s). From a sequence stratigraphic point of view, this condensed section, about $35 \mathrm{~cm}$ thick, can be identified on seismic profiles as a maximum flooding surface that marks the transition between delta retrogradation and delta progradation. The transition between the early Holocene deposits and the middle Holocene condensed section is marked by a gradual change in all proxy records. Following the stabilization of sea level at a global scale, the late Holocene is marked by the establishment of prodeltaic conditions at the core site, as shown by the lithofacies and by the presence of benthic meiofauna typical of the modern Rhône prodelta (e.g., Valvulineria bradyana, Cassidulina carinata, Bulimina marginata). Several periods of increased fluvial discharge are also emphasized by the presence of species com-
\end{abstract}

monly found in brackish and shallow-water environments (e.g., Leptocythere spp.). Some of these periods correspond to the multi-decadal to centennial late Holocene humid periods recognized in Europe (i.e., the $2.8 \mathrm{ka}$ event and the Little Ice Age). Two other periods of increased runoffs at ca. 1.3 and $1.1 \mathrm{kacal}$. BP are recognized, which are likely to reflect periods of regional climate deterioration that are observed in the Rhône watershed. Conversely, the Migration Period Cooling (ca. 1.4 ka cal. BP) and the Medieval Climate Anomaly (ca. AD 950-1250) correspond locally to periods of increased dryness.

\section{Introduction}

Deltas comprise a subaerial delta plain, where river processes dominate; a coarser-grained delta front, where river and basinal processes interact; and a muddy submarine prodelta dominated by oceanic processes (Bhattacharya and Giosan, 2003; Galloway, 1975; Postma, 1995). Most of the world's deltas were initiated during the early Holocene, between ca. 9.5 and $6 \mathrm{kacal}$. BP, owing to a deceleration of global sea-level rise (Stanley and Warne, 1994). They constitute key element of the continental margin system as they represent the first sink of sediments delivered by rivers (Trincardi et al., 2004).

Over the last decennia, numerous investigations have documented the land-sea evolution of these systems including the Amazon delta (Nittrouer et al., 1986), the Mekong delta (Ta et al., 2002; Xue et al., 2010), the Yellow River delta 
(J. P. Liu et al., 2004; Liu et al., 2007), and the delta of the Po River (Amorosi et al., 2008; Cattaneo et al., 2003). The Rhône delta is one of the most important of the Mediterranean Sea and has also been widely investigated combining seismic, sedimentological, and micropaleontological approaches (e.g., Boyer et al., 2005; Fanget et al., 2013a, b, 2014; Gensous et al., 1993; Labaune et al., 2005).

In this paper, we study the evolution of the Rhône prodelta in terms of sedimentary environments, during the last $10.5 \mathrm{kyr}$, as marked by changes in lithofacies and benthic meiofaunal assemblages (i.e., foraminifera and ostracods) and in relation to the Holocene sea-level rise and climate changes. This study shows that (1) major phases of sealevel rise and delta evolution can be clearly identified based on several independent proxy records, and that (2) changes in fluvial discharge inferred, in particular, from ostracod assemblages in the upper part of the core are linked to the last major periods of rapid climate changes of the Holocene (Mayewski et al., 2004; Wanner et al., 2014).

\section{Regional geological and climatic setting}

\subsection{Geological evolution of the Rhône subaqueous delta}

In the Gulf of Lion (NW Mediterranean), the Rhône delta (Fig. 1) occupies a deep valley incised during the Messinian and infilled with ca. $2 \mathrm{~km}$ of Plio-Quaternary sediments (Lofi et al., 2003), mainly delivered by the Rhône River (Aloïsi et al., 1977). For the last ca. $500 \mathrm{kyr}$, borehole data demonstrated that shelf deposits are primarily made up of forced-regressed sequences formed in response to $100 \mathrm{kyr}$ glacio-eustatic cycles (Bassetti et al., 2008; Frigola et al., 2012; Sierro et al., 2009). These authors also demonstrated that higher frequency cycles, as well as suborbital climate changes, were nicely recorded within paleo-prodeltaic sedimentary archives. Following the Last Glacial Maximum (LGM, ca. 21 ka cal. BP; Mix et al., 2001), rapid sea-level rise led to the retrogradation of Rhône delta, and formation of a wedge of transgressive (backstepping) deposits thickening landward. The most prominent feature is an elongated paleo-deltaic complex, named the Early Rhône Deltaic Complex (Berné et al., 2007), which formed during the Younger Dryas and the Preboreal (Fig. 1). After ca. 7 ka, stabilization of sea level allowed the progradation of a series of regressive deltaic lobes (Fanget et al., 2014), corresponding to the overall eastward migration of the Rhône distributaries. In total, these transgressive and regressive deposits form the Rhône subaqueous delta that reaches, along the modern delta front, up to $50 \mathrm{~m}$ in thickness and pinches out at a present water depth of ca. $90 \mathrm{~m}$ (Gensous and Tesson, 1997).

The early Holocene deposits (called seismic unit U500), which rest on a wave ravinement surface (called D500), formed a transgressive parasequence (Labaune et al., 2005) made of tempestite deposits (Fanget et al., 2014). They are separated from middle and late Holocene deposits by a con- densed section which corresponds on seismic profile to a maximum flooding surface (MFS, called D600). The age of the MFS varies along-strike between ca. 8 and $3 \mathrm{kacal}$. BP, and reflects, at a given site, the duration of condensation and/or erosion (Fanget et al., 2014). After the stabilization of global sea level (ca. $7 \mathrm{kacal}$. BP), the middle and late Holocene Rhône outlets shifted progressively eastward, under natural and/or anthropic influence. As a result, several deltaic lobes are formed (Fig. 1) (Arnaud-Fassetta, 1998; L'Homer et al., 1981; Provansal et al., 2003; Rey et al., 2005; Vella et al., 2005, 2008). Saint Ferréol, which is related to the "Rhône de Saint Ferréol" Channel, is the first and largest paleo-deltaic lobe. It started to prograde around $7 \mathrm{kacal}$. BP (L'Homer et al., 1981). The Ulmet lobe, located to the east and linked to the "Rhône d'Ulmet" Channel formed simultaneously to the Saint Ferréol lobe. To the west of the Saint Ferréol lobe, the Peccais lobe, related to the "Rhône de Peccais" Channel, appeared to be posterior to the erosion of the St Ferréol lobe (Rey et al., 2005; Vella et al., 2005). During the Little Ice Age, the Bras de Fer lobe, linked to the "Rhône de Bras de Fer" Channel, formed between AD 1587 and 1711 (Arnaud-Fassetta, 1998). Until AD 1650, the "Rhône de Bras de Fer" Channel is considered as synchronous to the "Rhône du Grand Passon" Channel (Arnaud-Fassetta, 1998). The "Rhône de Bras de Fer" Channel shifted to the east up to the present-day position of the Grand Rhône River after several severe floods that occurred in AD 1709-1711. The progradation of these lobes is primarily influenced by changes in sediment fluxes and thus by climate (Arnaud-Fassetta, 2002; Bruneton et al., 2001; Provansal et al., 2003).

\subsection{Holocene climate and its regional characteristics}

High fluctuations in rainfall and low-amplitude temperature variations are observed during the Holocene (Davis et al., 2003; Mayewski et al., 2004; Seppä et al., 2009; Wanner et al., 2008, 2011). Examination of globally distributed paleoclimate records led to identification of six multi-decadal to century-scale cooling events interrupting periods of relatively stable and warmer climate (Mayewski et al., 2004; Wanner et al., 2008, 2011, 2014). These periods are known as rapid climate changes (RCCs; Mayewski et al., 2004) or cold relapses (CRs; Bassetti et al., 2016; Jalali et al., 2016; Wanner et al., 2014). The $8.2 \mathrm{kacal}$. BP cold relapse (CR0, Table 1) took place at the beginning of the Holocene (Barber et al., 1999), a period of progressive warming that induced ice cap melting and freshwater outbursts to the oceans from North American glacial lakes.

During the warm middle Holocene, several significant episodes were identified at $6.4,5.3$, and $4.2 \mathrm{ka} \mathrm{cal}$. BP (CR1, CR2, and CR3, respectively; Table 1) (Walker et al., 2012; Wanner et al., 2014). The $4.2 \mathrm{ka}$ event, which may have played a role in the collapse of various civilizations (Magny et al., 2013), is characterized by increased drought in North America, Asia, and the southern Mediterranean region. 


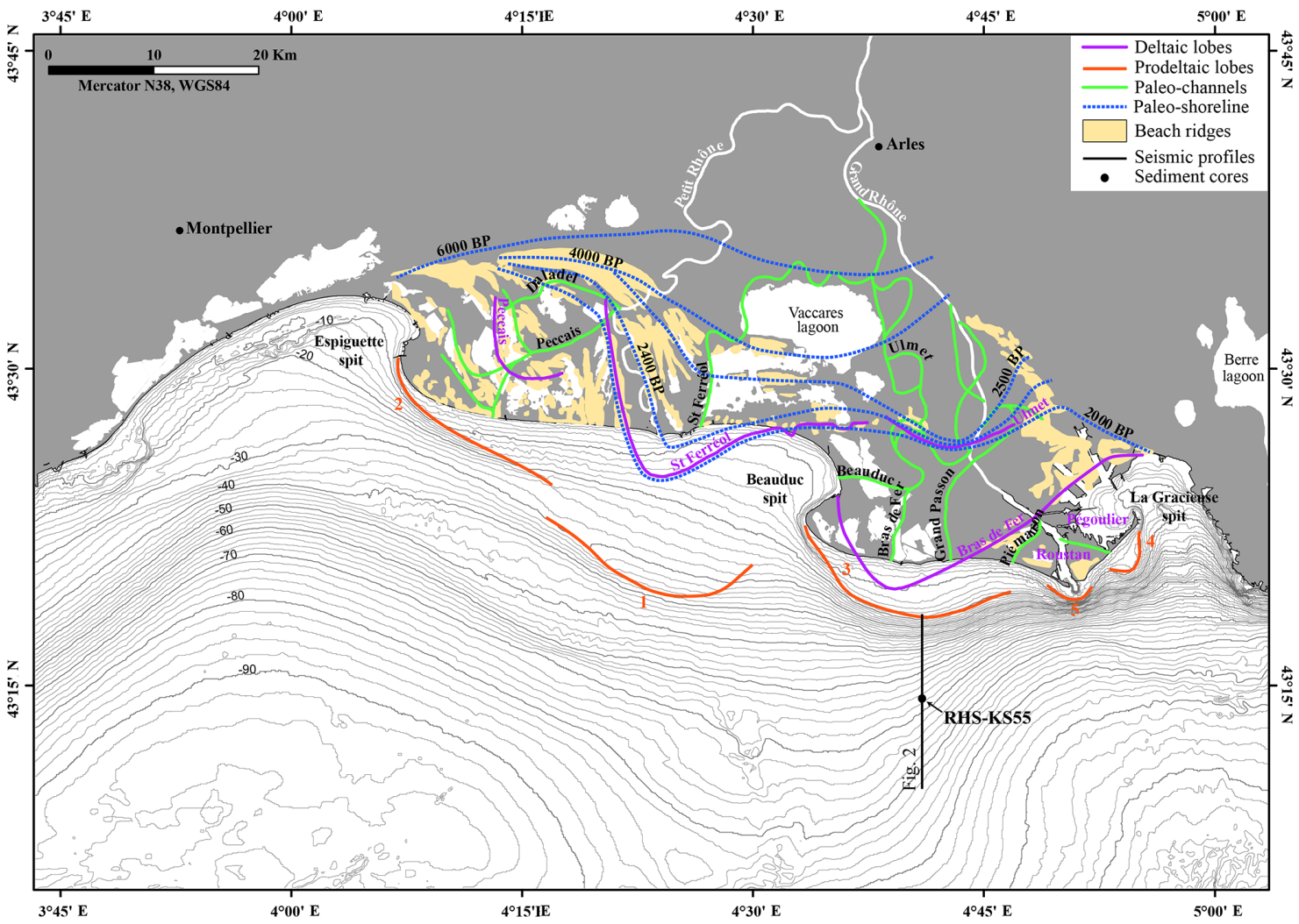

Figure 1. Offshore and onshore morphology of the Rhône deltaic system. This map is based on the compilation of Berné et al. (2007) and Vella et al. (2008). The successive shifting of the Rhône distributaries under natural and/or anthropic influence during the middle and late Holocene led to the formation of several deltaic lobes. Steps in the present-day morphology correspond to the position of the paleo-delta fronts that can be linked to known paleo-distributaries of the Rhône: (1) early Saint Ferréol, (2) Peccais, (3) Bras de Fer, (4) Pégoulier, and (5) modern Roustan distributary. The map of relict morpho-sedimentary units in the Rhône delta plain (paleo-shorelines, beach ridges and onshore deltaic lobes) is based on L'Homer et al. (1981), Arnaud-Fassetta (1998), Vella (1999), and Provansal et al. (2003). Thick line and black dot correspond respectively to chirp seismic profile (Fig. 2) and sediment core RHKS-55 presented in this study.

Table 1. Chronology of Holocene cold relapses (CRs) based on existing literature.

\begin{tabular}{lrl}
\hline Event & $\begin{array}{r}\text { Time slice } \\
(\mathrm{kyr})\end{array}$ & References \\
\hline CR0 & 8.2 & Barber et al. (1999) \\
CR1 & $6.4-6.2$ & Wanner et al. (2011) \\
CR2 & $5.3-5.0$ & Magny and Haas (2004); \\
& & Roberts et al. (2011) \\
CR3 & $4.2-3.9$ & Walker et al. (2012) \\
CR4 & $2.8-3.1$ & Chambers et al. (2007); \\
& & Swindles et al. (2007) \\
CR5 & $1.45-1.65$ & Wanner et al. (2011) \\
CR6 & $0.65-0.15$ & Wanner et al. (2011) \\
\hline
\end{tabular}

During the cooler late Holocene, the $2.8 \mathrm{ka}$ cal. BP cold period (CR4, Table 1) might be at the origin of the decline of the Late Bronze Age civilization (Do Carmo and Sanguinetti, 1999; Weiss, 1982), and CR5 (Table 1) matches the Migra- tion Period that occurred around $1.4 \mathrm{ka} \mathrm{cal}$. BP (Wanner et al., 2014). The late Holocene cooling trend reached the highest development during the Little Ice Age (LIA, CR6 in Table 1) between the 13th and 19th centuries (Frezza and Carboni, 2009)

In the Rhône catchment area, these CRs (or at least CR0 and CR6) are marked by increased river runoff. CR0, or the so-called $8.2 \mathrm{ka}$ event (Alley et al., 1997), is indeed marked by high lake levels generated by more intense rainfall (Magny and Begeot, 2004; Magny et al., 2003). The LIA (CR6), which is well documented in the Rhône watershed, is marked by a period of significant Alpine glacier advance (Goehring et al., 2011; Ivy-Ochs et al., 2009), high lake levels (Magny et al., 2010), and an increase in Rhône River floods (Pichard, 1995; Pichard and Roucaute, 2014).

\section{Material and methods}

The present paper is based on a multi-proxy study of a $7.38 \mathrm{~m}$ long piston core (RHS-KS55) collected in front 
of the paleo-"Rhône de Bras de Fer" and "Grand Passon" channels at $67 \mathrm{~m}$ water depth (latitude $=43^{\circ} 14.35^{\prime} \mathrm{N}$; longitude $=4^{\circ} 40.96^{\prime} \mathrm{E}$ ) during the RHOSOS oceanographic cruise (R/V Le Suroît, September 2008).

The detailed architecture of the Rhône subaqueous delta was determined from high-resolution seismic data (2000$5200 \mathrm{~Hz}$ Chirp system), together with core data constrained by ${ }^{14} \mathrm{C}$ dates (Fanget et al., 2014). Radiometric dates were measured with accelerator mass spectrometer (AMS) ${ }^{14} \mathrm{C}$ on benthic foraminifera or shells at Poznan Radiocarbon Laboratory (PRL, Poland) and at Laboratoire de Mesure ${ }^{14} \mathrm{C}$ (LMC14) at Commissariat à l'Energie Atomique (CEA, France). Nevertheless, because of the low quantity of biogenic carbonates in the proximal part of the Rhône prodelta, we experienced difficulties in dating core RHS-KS55 and observed three age inversions from 336 to $122 \mathrm{~cm}$. Based on seismic and lithofacies correlations at the regional scale (Fanget et al., 2014), we excluded these three ${ }^{14} \mathrm{C}$ dates for core RHS-KS55. We also excluded the three older ${ }^{14} \mathrm{C}$ dates (unit U500, base of the core) since measured ages are considered older than true ages (due to incorporation of reworked benthic foraminifera; for more information, see Sects. 4.1 and 5.1). As a result, eight robust ${ }^{14} \mathrm{C}$ dates were used to create the age model for the last ca. $9 \mathrm{kyr}$. Ages are $\delta^{13} \mathrm{C}$ normalized conventional ${ }^{14} \mathrm{C}$ years and are corrected for an assumed air-sea reservoir effect of 400 years. Calendar ages were calculated using the program Clam (version 2.2, Blaauw, 2010) and the Marine13 calibration curve (Reimer et al., 2013). The age model was based on the linear interpolation between the dated levels using basic (non-Bayesian) age-depth modeling software (Blaauw, 2010).

Core RHS-KS55 was split lengthwise, imaged, and visually described for identifying sedimentological facies. Core RHS-KS55 was then subsampled for benthic microfaunal analyses (i.e., ostracods and foraminifera) and clay mineralogy. Three-centimeter-thick slides were collected using a $10 \mathrm{~cm}$ sampling step through the core, except from the bottom of the core to ca. $500 \mathrm{~cm}$, where thick slides and sampling step were slightly modified. A total of 79 samples were sieved through a $63 \mu \mathrm{m}$ mesh screen and the residues were dried and dry-sieved using a 125 and $150 \mu \mathrm{m}$ mesh screens. Ostracods and benthic foraminifera were hand-sorted from the $>125$ and $>150 \mu \mathrm{m}$ fractions, respectively, and stored in Plummer slides. To illustrate the diversity of benthic meiofauna, total abundance (values normalized for a $100 \mathrm{~cm}^{3}$ sample volume), species richness $(S)$, Shannon index $(H)$, and evenness index $(E)$ (Hayek and Buzas, 1997; Shannon, 1948) were calculated, as described in Murray (2006), for each level. To highlight vertical patterns in benthic meiofaunal communities, hierarchical clustering was also performed on the 79 samples and on the major species (i.e., occurring with more than $5 \%$ in at least one sample) by mean of the PAST ${ }^{\odot}$ software (version 2.09, 2011; Hammer et al., 2001). Cluster analyses were based on the arcsine values of the square of root "pi", where "pi" is the relative abundance
(\%) of the species $i$ divided by 100. A tree diagram was constructed according to the Ward's method based on the squared Euclidean distances.

The fraction less than $63 \mu \mathrm{m}$ was used to perform clay mineral analyses. X-ray diffraction (XRD) on oriented mounts of carbonate-free clay-sized $(<2 \mu \mathrm{m})$ particles was conducted to identify clay minerals with the PANalytical diffractometer, following the routine of the GEOPS Laboratory (Paris Sud University, France) (Z. Liu et al., 2004; Liu et al., 2008). Three XRD runs were carried out, following air drying, ethylene-glycol solvation over $24 \mathrm{~h}$, and heating at $490^{\circ} \mathrm{C}$ over $2 \mathrm{~h}$. The position of the (001) series of basal reflections on the three XRD diagrams was used to identify clay minerals. Semi-quantitative estimates of peak areas of the basal reflections for the main clay mineral assemblages of illite $(10 \AA)$ ), smectite (including mixed layers) (15-17 $\AA$ ), and kaolinite / chlorite $(7 \AA)$ were performed on the glycolated curve using the MacDiff software (Petschick, 2000). Relative proportions of kaolinite and chlorite were determined using the ratio $3.57 / 3.54 \AA$ of the peak areas.

\section{Results}

\subsection{Seismic stratigraphic framework, age model, and sedimentation rates}

Seismic discontinuities and seismic units described in the following section are based on Fanget et al. (2014). Several deglacial and Holocene seismic units bounded by wellmarked discontinuities are identified at the core site (Fig. 2). Seismic data show that core RHS-KS55 goes through surface D500 and represents an expanded record of seismic units U500, U600, and U610. Seismic unit U620a is missing in the studied core (Fig. 2).

The age of seismic unit U500, which corresponds to the early Holocene transgressive parasequence (Fanget et al., 2014), is poorly constrained in core RHS-KS55 (Figs. 3 and 4). Considering the age of the underlying deposits of seismic unit U400 in this area (i.e., paleo-deltaic complex of the Rhône (ERDC), ca. 10.5 ka cal. BP; Berné et al., 2007), we assume that the three ${ }^{14} \mathrm{C}$ dates obtained at 732,672 , and $512 \mathrm{~cm}$ (i.e., $12.7,13.3$, and $12.2 \mathrm{kacal}$. BP, respectively) are biased (Fig. 4) because of reworking occurring in shallow-water environments. This interpretation is supported by the nature of sediments that composed this unit. Indeed, at the regional scale, seismic unit U500 is made of tempestite deposits (Facies 1, Sect. 4.2.) which mainly contain infra-littoral (i.e., upper shoreface) benthic foraminifera (e.g., Elphidium crispum; see Table 2 and Fanget et al., 2014). These infra-littoral benthic foraminifera are likely reworked by high-energy hydrodynamic processes that regularly winnowed the seafloor. The three older ages obtained within seismic unit U500 are thus probably the result of reworking during the transgression of an underlying Younger Dryas/Preboreal delta front. It is likely that infra-littoral ben- 


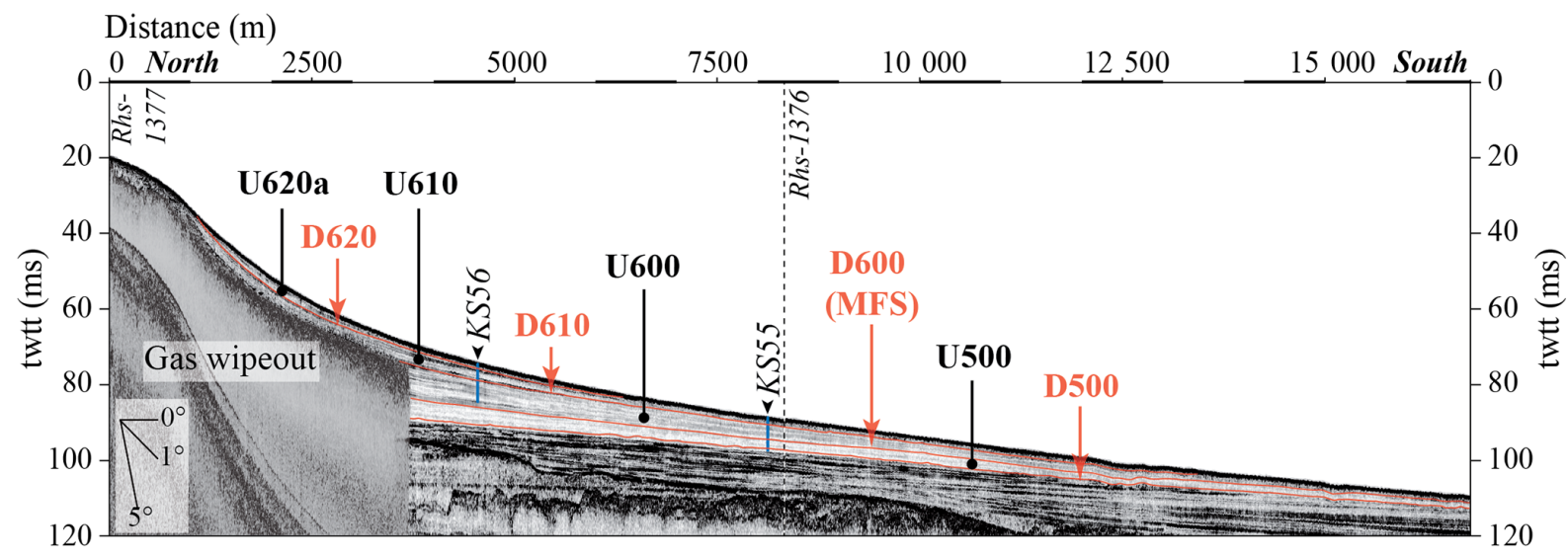

Figure 2. "Dip" (NS) chirp seismic profile across the Grand Passon and Bras de Fer subaqueous delta (position in Fig. 1). Surface D500 corresponds to the flooding surface (which coincides here with a wave ravinement surface) that separates the Younger Dryas (seismic unit U400) deposits from the Preboreal deposits (seismic unit U500). The downlap surface D600 is the maximum flooding surface formed during the turnaround between retrogradation and progradation. D610 and D620 are erosional surfaces that mimic flooding surfaces and separate the middle and late Holocene sedimentary wedges (seismic units U600, U610, and U620a) formed in response to the successive shifts of Rhône Channel. Twtt: two-way travel time.

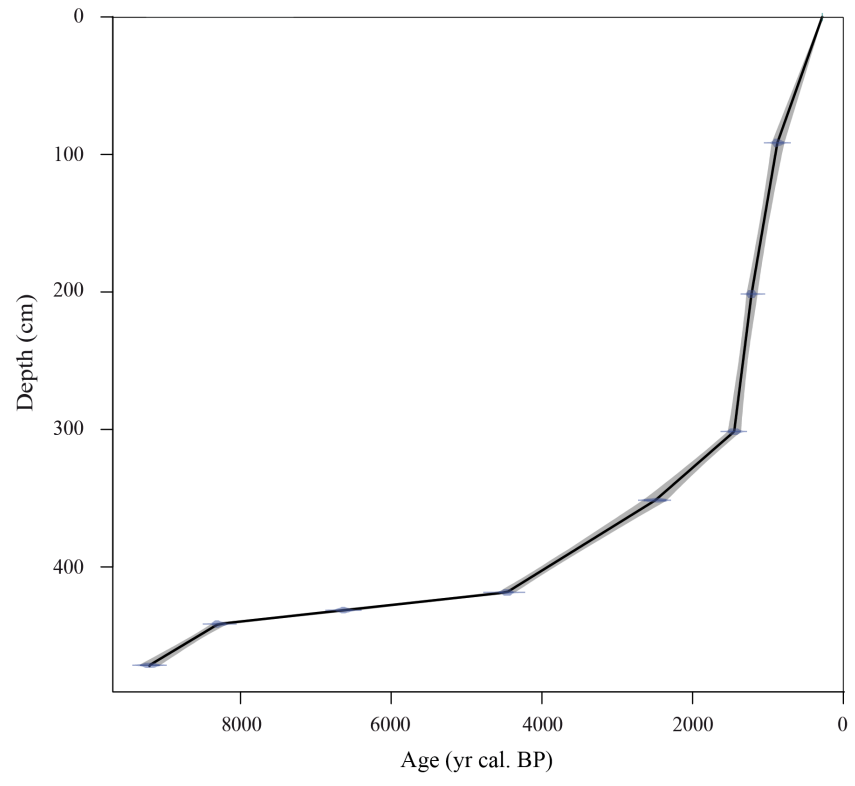

Figure 3. Age model for the upper part (i.e., from 472 to $0 \mathrm{~cm}$; middle and late Holocene) of core RHS-KS55 based on linear interpolation using the Clam 2.2 software (Blaauw, 2010).

thic foraminifera picked for these three ${ }^{14} \mathrm{C}$ dates are reworked from older deposits (for more details, see Sect. 5.1).

Only the uppermost part of this unit is confidently dated between ca. 9.2 and $8.3 \mathrm{kacal}$. BP (Table 2). The upper boundary of seismic unit U500, called D600 and interpreted as a MFS (Fanget et al., 2014), corresponds to a condensed section formed between ca. 8.3 and $4.5 \mathrm{ka} \mathrm{cal}$. BP in the studied core (Fig. 3). It is characterized by a very low sedimentation rate of ca. $0.01 \mathrm{~cm} \mathrm{yr}^{-1}$ (Fig. 4). Seismic unit U600 progrades on D600, and is related to the marine component of the St Ferréol and Ulmet lobes (Fanget et al., 2014). ${ }^{14} \mathrm{C}$ dates indicate that seismic unit U600 was deposited between ca. 4.5 and 0.9 ka cal. BP (Fig. 3). Sedimentation rates through this interval oscillated between 0.03 and $0.4 \mathrm{~cm} \mathrm{yr}^{-1}$ (Fig. 4). Highest sedimentation rates are recorded along the uppermost part of this unit (i.e., between 300 and $110 \mathrm{~cm}$, Fig. 4). Finally, seismic unit U610, corresponding to the activity of the Grand Passon and Bras de Fer channels, was formed between ca. 900 and $280 \mathrm{yr}$ cal. BP (Fig. 3) (Fanget et al., 2014). As seismic unit U620a is missing within core RHS-KS55, we estimate that the top of the core has an age of ca. $280 \mathrm{yr}$ cal. BP. Sedimentation rate through seismic unit U610 is estimated at ca. $0.11 \mathrm{~cm} \mathrm{yr}^{-1}$ (Fig. 4).

\subsection{Sedimentary features}

Based on lithological description (including lithofacies, sedimentary structures, bioturbation, and color) of core RHSKS55 (Fanget et al., 2014), three main sedimentary facies (i.e., Facies 1, 2, and 3 (including $3 \mathrm{a}$ and $\mathrm{b}$ )) are identified and summarized as follows:

- Facies 1: from 738 (core bottom) to $460 \mathrm{~cm}$, core RHSKS55 consists of numerous silt or very fine sand laminae (in the sense of Campbell, 1967) interlaminated with grayish and beige silty clay with spacing of millimeters to several centimeters (Fig. 4). Within these very thin laminae (millimeters to a few centimeters thick), which are characterized by erosional basal contacts, no sedimentary structures can be identified.

- Facies 2: from 460 to $430 \mathrm{~cm}$, a peculiar interval consisting of heterolithic content in a grayish silty clay ma- 
Table 2. Summary of ${ }^{14} \mathrm{C}$ dates. Absolute dates were obtained with accelerator mass spectrometer (AMS) ${ }^{14} \mathrm{C}$ dating of well-preserved shells and benthic foraminifera at Laboratoire de Mesure ${ }^{14} \mathrm{C}(\mathrm{LMC} 14)$ at Commissariat à l'Energie Atomique (CEA, Saclay) and at Poznan Radiocarbon Laboratory (PRL). The ages reported herein are delta ${ }^{13} \mathrm{C}$-normalized conventional ${ }^{14} \mathrm{C}$ years, corrected for an assumed air-sea reservoir effect of 400 years. Calendar ages were calculated using Clam software (Blaauw, 2010) and the Marine13 calibration curve (Reimer et al., 2013).

\begin{tabular}{|c|c|c|c|c|c|c|}
\hline $\begin{array}{l}\text { Depth } \\
(\mathrm{cm})\end{array}$ & Material & $\begin{array}{r}\text { Weight } \\
(\mathrm{mg})\end{array}$ & $\begin{array}{l}\text { Sample } \\
\text { number }\end{array}$ & $\begin{array}{r}{ }^{14} \mathrm{C} \text { conventional } \\
\text { age }(\mathrm{yr} \mathrm{BP})\end{array}$ & $\begin{array}{r}\text { Calibrated age } \\
\text { (yr cal. BP) }\end{array}$ & $\begin{array}{r}\text { Mean calibrated } \\
\text { age (yr cal. BP) }\end{array}$ \\
\hline $90-93$ & Benthic foraminifera & 9.5 & SacA 27201 & $1335 \pm 30$ & 790-944 & 867 \\
\hline $120-123$ & Benthic foraminifera & 9.9 & SacA 27202 & $1840 \pm 30$ & $1300-1477$ & $1389 *$ \\
\hline $150-153$ & Benthic foraminifera & 11 & SacA 23204 & $2080 \pm 35$ & $1551-1761$ & $1656^{*}$ \\
\hline $200-203$ & Benthic foraminifera & 10.6 & SacA 23205 & $1655 \pm 30$ & $1154-1282$ & 1218 \\
\hline $300-303$ & Benthic foraminifera + Turritella sp. & 10.9 & SacA 23206 & $1900 \pm 30$ & $1362-1527$ & 1445 \\
\hline $335-336$ & $\begin{array}{l}\text { Benthic foraminifera }+ \text { Turritella } \mathrm{sp} \text {. } \\
+ \text { mixed bivalves }\end{array}$ & 10 & SacA 23207 & $1705 \pm 30$ & 1185-1318 & $1252^{*}$ \\
\hline $350-353$ & Benthic foraminifera & 11.3 & SacA 27203 & $2760 \pm 35$ & $2351-2619$ & 2485 \\
\hline $417-420$ & Turritella sp. & 896 & Poz-35061 & $4335 \pm 35$ & $4375-4574$ & 4475 \\
\hline $430-433$ & Benthic foraminifera & 10.5 & SacA 27204 & $6190 \pm 40$ & $6513-6735$ & 6624 \\
\hline $440-443$ & Nucula sp. & 11.2 & SacA 27205 & $7830 \pm 40$ & 8192-8374 & 8283 \\
\hline $470-473$ & Benthic foraminifera & 10.2 & SacA 23208 & $8565 \pm 35$ & $9075-9333$ & 9204 \\
\hline $510-513$ & Elphidium crispum & 10.1 & SacA 23209 & $10790 \pm 40$ & $12058-12467$ & $12263^{*}$ \\
\hline $670-673$ & Benthic foraminifera & 13 & SacA 23210 & $11855 \pm 45$ & $13215-13433$ & $13324^{*}$ \\
\hline $730-733$ & Elphidium crispum & 10.6 & SacA 23211 & $11280 \pm 40$ & $12644-12870$ & $12757^{*}$ \\
\hline
\end{tabular}

Mean calibrated ages with an asterisk were excluded from the age model since they are considered biased (see text for more details).

trix is observed (Fig. 4). Turritella sp., as well as several bivalves (e.g., Acanthocardia echinata, Arca tetragona, Nucula sp.) and bryozoans, is identified.

- Facies 3a: from 430 to $320 \mathrm{~cm}$, sediment consists of beige silty clay without visible sedimentary structures. Diffuse veneers of yellowish lighter levels and spots of darker deposits (richer in hydrotroilite), clearly obliterated by intense bioturbation, are observed (Fig. 4). Scattered bryozoans debris, Turritella sp., and bivalves are encountered in this interval.

- Facies 3b: from 320 to $0 \mathrm{~cm}$, sediment consists of grayish and beige silty clay and contains abundant hydrotroilites and bioturbation.

\subsection{Clay mineralogy}

Clay mineral assemblages are dominantly composed of illite, with values ranging from ca. 55 to $85 \%$ (Fig. 5). Illite content exhibits high and quite constant values (ca. $70 \%$ ) from the bottom of the core to $465 \mathrm{~cm}$. From 455 to $360 \mathrm{~cm}$, illite content decreases to ca. $60 \%$. A strong increase is observed at $340 \mathrm{~cm}$, with values reaching ca. $80 \%$. Illite content remains high between 340 and $110 \mathrm{~cm}$. At $110 \mathrm{~cm}$, illite content drops to ca. $55 \%$ and is generally lower from 100 to $30 \mathrm{~cm}$. Along the uppermost $30 \mathrm{~cm}$ of the core, a progressive increase in illite content is identified. Smectite content is inversely correlated to illite content throughout core RHS-KS55 (Fig. 5). It has very low values (ca. $2.5 \%$ ) from 738 to $465 \mathrm{~cm}$ and exhibits higher (from ca. 5 to $25 \%$ ) and erratic values along the uppermost $460 \mathrm{~cm}$ of the core. Chlorite content reaches ca. $20 \%$ in the lower part of the core (from the bottom to $350 \mathrm{~cm}$ ) and drops near $0 \%$ between 350 and $120 \mathrm{~cm}$ (Fig. 5). Chlorite content increases to ca. $20 \%$ along the uppermost $120 \mathrm{~cm}$ of the core. Kaolinite content is very low throughout core RHS-KS55 with values close to $0 \%$ from the bottom of the core to $360 \mathrm{~cm}$, and ranging from ca. 7 to $10 \%$ between $360 \mathrm{~cm}$ and the top of the core (Fig. 5).

\subsection{Ostracod fauna}

\subsubsection{Ostracod density and diversity indices}

The number of ostracods per sample varies greatly from 68 to 12821 ind. $/ 100 \mathrm{~cm}^{3}$ in core RHS-KS55 (Fig. 6). From the base of the core to $482 \mathrm{~cm}$, density ranges from 68 to 1266 ind. $/ 100 \mathrm{~cm}^{3}$. The lowest values are observed from 642 to $632 \mathrm{~cm}$, whereas four peaks of $1141,1243,1006$, and 1266 ind. $/ 100 \mathrm{~cm}^{3}$ are identified at $702,622,571$, and $541 \mathrm{~cm}$, respectively. From 471 to $352 \mathrm{~cm}$, the number of counted ostracods increases strongly with values reaching up to 12821 ind. $/ 100 \mathrm{~cm}^{3}$ and 10539 ind. $/ 100 \mathrm{~cm}^{3}$ at 432 and $412 \mathrm{~cm}$, respectively. The number of ostracods per sample drops to $222 \mathrm{ind} . / 100 \mathrm{~cm}^{3}$ at $332 \mathrm{~cm}$ and ranges from 305 to 1182 ind. $/ 100 \mathrm{~cm}^{3}$ between 322 and $162 \mathrm{~cm}$. Density decreases between 152 and $82 \mathrm{~cm}$ and then increases progressively along the uppermost $82 \mathrm{~cm}$ of the core.

Species richness $(S)$ oscillates between 7 and 31 species per sample through the core and approximately follows the 


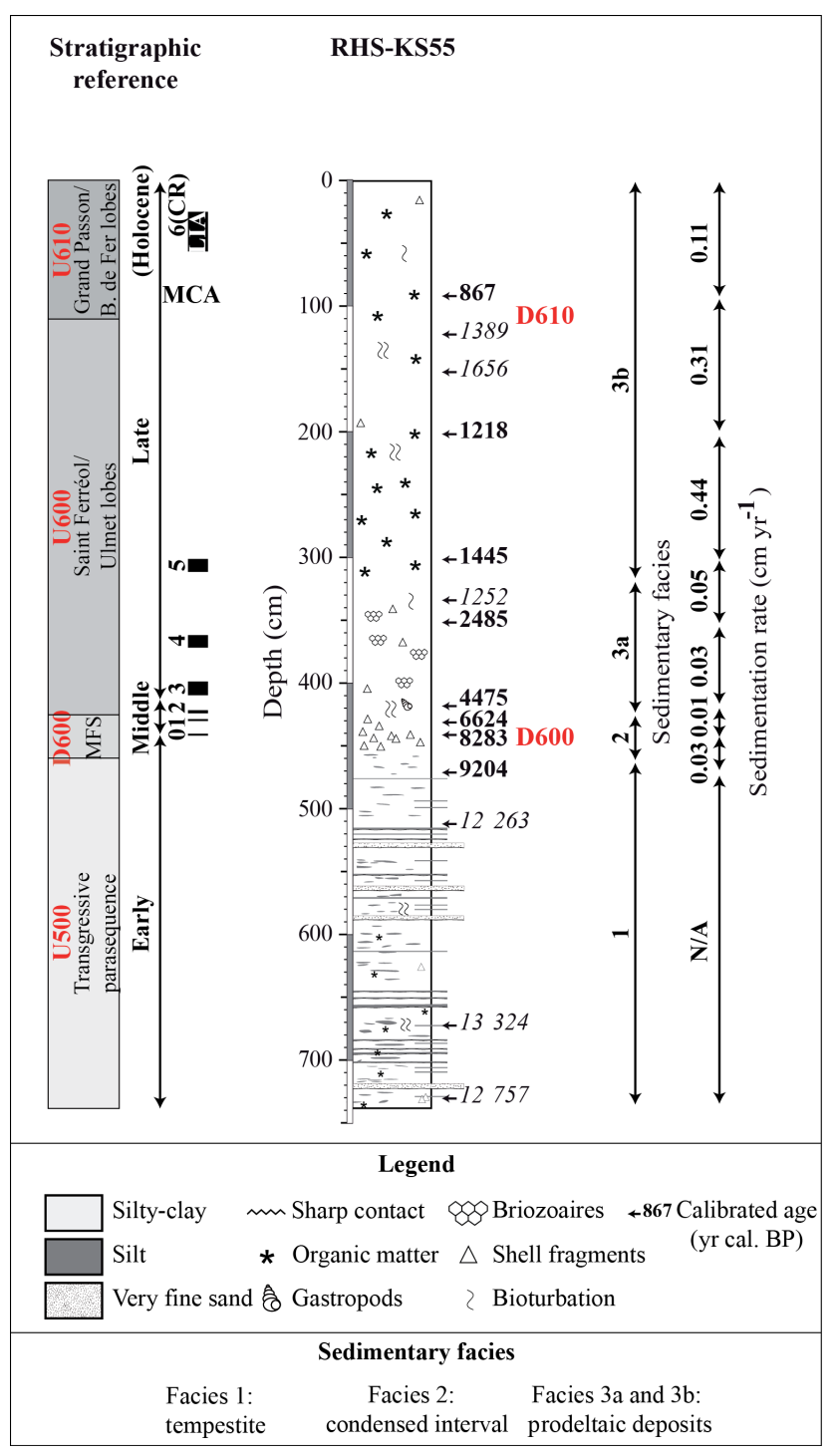

Figure 4. Sediment features and sedimentation rates of core RHSKS55. Correlations with seismic units and discontinuities and with the Holocene chronology are shown on the left side of the figure. Black rectangles represent the most significant periods of climate deterioration (known as cold relapses (CRs); Wanner et al., 2014) during the Holocene (e.g., the $8.2 \mathrm{ka}$ event (CR0) and the Little Ice Age (CR6)). AMS ${ }^{14} \mathrm{C}$ dates are mentioned to the right; italic values correspond to age inversions. ${ }^{14} \mathrm{C}$ dates are summarized in Table 2.

same trend as density (Fig. 6). Lowest values of $S$ are recorded when ostracods abundances are minimal, i.e., at 642 and $632 \mathrm{~cm}$ and between 152 and $82 \mathrm{~cm} . S$ is maximal within the interval between 482 and $442 \mathrm{~cm}$. The Shannon index $(H)$ varies between 1.2 and 3.0 through the core (Fig. 6). $H$ increases progressively from the base of the core to $492 \mathrm{~cm}$. $H$ reaches maximal values (ca. 3.0) between 482 and $442 \mathrm{~cm}$ and decreases progressively from 433 to $82 \mathrm{~cm}$. Along the uppermost $82 \mathrm{~cm}$ of the core, $H$ gradually increases (from ca. 1.4 to 2.2). The evenness index $(E)$, which is between 0.2 and 0.7 , follows approximately the same trend as $H$ (Fig. 4). The lowest values of $E$ are observed from 738 to $492 \mathrm{~cm}$, whereas the maximal values are observed from 482 to $422 \mathrm{~cm}$. $E$ is relatively constant along the uppermost $412 \mathrm{~cm}$ of the core, with values oscillating around 0.5 .

\subsubsection{Cluster analysis}

R-mode cluster analysis allows us to identify six ostracod clusters plus one single species when a cut-off level of 1.4 is applied (Figs. 7 and 8).

Cluster A is made of Semicytherura incongruens, Pontocythere elongata, and Semicytherura sp. It has a maximal contribution from 738 to $512 \mathrm{~cm}$, with erratic values ranging from ca. 5 to $25 \%$. It decreases strongly from 512 to $442 \mathrm{~cm}$ and disappears completely along the uppermost $432 \mathrm{~cm}$ of the core.

Cluster B is composed of Propontocypris pirifera, Cytherissa sp., Eucythere sp., Aurila sp., and Cytheridea neapolitana. It shows a low contribution through the core, with values generally $<10 \%$. It increases only between 482 and $442 \mathrm{~cm}$, where a maximal value of $25 \%$ is reached.

Cluster C is constituted by Cytherella sp., Cytheropteron alatum, Cytheropteron monoceros, and Carinocythereis carinata. It exhibits a low contribution $(<10 \%)$ from 738 to $492 \mathrm{~cm}$. It increases strongly between 492 and $372 \mathrm{~cm}$, to reach up to ca. $40 \%$ of the ostracod fauna at $432 \mathrm{~cm}$. Cluster $\mathrm{C}$ decreases progressively, and has a minimal contribution along the uppermost $362 \mathrm{~cm}$ of the core.

The single species corresponds to Leptocythere spp. This species dominates ostracod fauna from 738 to $492 \mathrm{~cm}$, with values ranging from ca. 41 to $73 \%$. Along the uppermost $492 \mathrm{~cm}$ of the core, Leptocythere spp. oscillates between low $(<5 \%)$ and high (ca. 30-40\%) values. The lowest contributions of this species are recorded from 472 to 432,332 to 302,232 to 182 , and 122 to $82 \mathrm{~cm}$.

Cluster D is made of Cytheropteron rotundatum and Krithe spp. (juvenile Krithe and K. pernoides). From 738 to $362 \mathrm{~cm}$, it has a low contribution $(<5 \%)$. It increases strongly along the uppermost $352 \mathrm{~cm}$ of the core, with values ranging from ca. 30 to $60 \%$, and reaches a peak of ca. $77 \%$ at 92 and $82 \mathrm{~cm}$.

Cluster E is composed of Argilloecia spp., Loxoconcha laevis, and Paradoxostoma sp. It exhibits a moderate contribution through the core, with values oscillating generally between ca. 5 and $15 \%$. However, four peaks of ca. 37, 45, 35 , and $27 \%$ are recorded at $492,342-332,112$, and $72 \mathrm{~cm}$, respectively.

Cluster F is constituted by Sagmatocythere sp., Bosquetina dentata, and Pterigocythereis jonesii. It shows a minimal contribution $(<5 \%)$ from 738 to $492 \mathrm{~cm}$. It increases between 482 and $162 \mathrm{~cm}$, with values ranging from ca. 20 to $35 \%$, except between 352 and $332 \mathrm{~cm}$, where a decrease $(<15 \%)$ is observed. From 162 to $72 \mathrm{~cm}$, Cluster F exhibits 


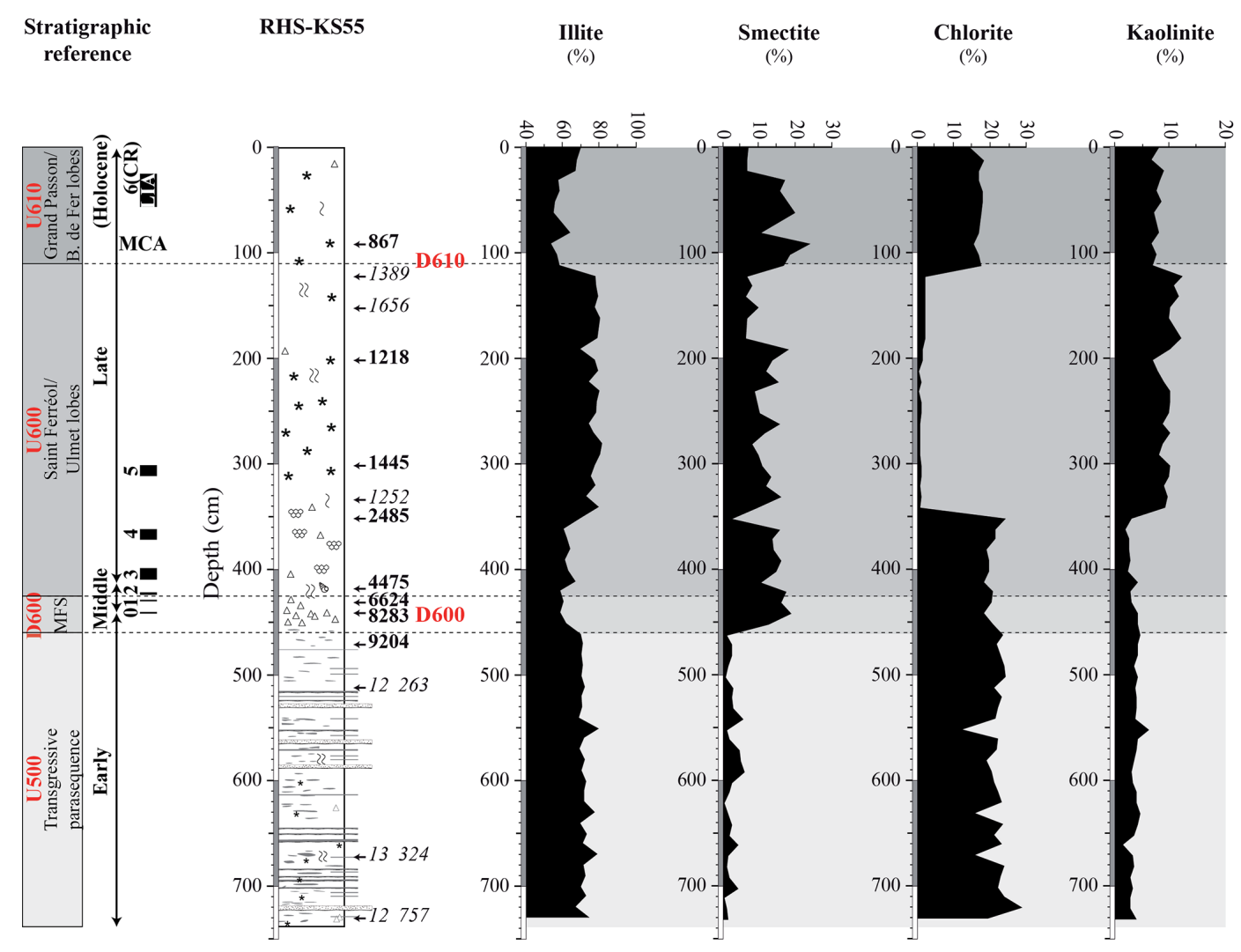

Figure 5. Distribution of the main clay minerals in core RHS-KS55. Correlations with seismic units and discontinuities are shown on the left side of the figure. The corresponding positions of seismic units and discontinuities (U500, U600, U610, D600, and D610) are also reported on the plots (gray bands and dashed lines). Black rectangles on the left side of the figure represent the most significant periods of climate deterioration (i.e., cold relapses (CRs)) during the Holocene.

erratic values oscillating between ca. 2 and $20 \%$. Along the uppermost $72 \mathrm{~cm}$ of the core, it increases slightly.

\subsection{Benthic foraminiferal fauna}

\subsubsection{Benthic foraminiferal density and diversity indices}

The number of benthic foraminifera per sample varies greatly from 404 to 74642 ind. $/ 100 \mathrm{~cm}^{3}$ through the core (Fig. 6). From 738 to $482 \mathrm{~cm}$, density shows erratic values oscillating between 404 and 7130 ind. $/ 100 \mathrm{~cm}^{3}$ and increases progressively. The number of counted specimens increases strongly between 472 and $382 \mathrm{~cm}$, with values ranging from 12386 to 74642 ind./100 $\mathrm{cm}^{3}$. From 382 to $352 \mathrm{~cm}$, density decreases rapidly and drops to $2995 \mathrm{ind} . / 100 \mathrm{~cm}^{3}$. Along the uppermost $342 \mathrm{~cm}$ of the core, benthic foraminiferal densities remain quite constant and below 3000 ind. $/ 100 \mathrm{~cm}^{3}$.

Species richness $(S)$ oscillates between 13 and 49 species per sample through the core (Fig. 6). The lowest values of $S$ (from 13 to 26) are recorded from 738 to $632 \mathrm{~cm} . S$ increases from 622 to $492 \mathrm{~cm}$, except between 542 and $532 \mathrm{~cm}$, where a decreased is observed. The highest values of $S$ are encountered from 482 to $212 \mathrm{~cm}$, with values oscillating between 34 and 49 species per sample. $S$ slightly decreases along the uppermost $202 \mathrm{~cm}$ of the core and remains quite constant. The Shannon index $(H)$ varies between 1.2 and 3.2 through the core RHS-KS55 (Fig. 6). From 738 to $642 \mathrm{~cm}, H$ decreases progressively from 2.3 to 1.2 . Erratic values, oscillating between 1.6 and 2.7, are observed from 632 to $492 \mathrm{~cm}$. Even if $H$ slightly decreased between 452 and $402 \mathrm{~cm}$, the highest values are recorded between 482 and $352 \mathrm{~cm}$. From 342 to $132 \mathrm{~cm}, H$ decreases progressively, whereas it increases slightly along the uppermost $122 \mathrm{~cm}$ of the core. The evenness index $(E)$ exhibits relatively low values through the core, ranging from 0.2 to 0.5 , and follows exactly the same trend as $H$ (Fig. 6).

\subsubsection{Cluster analysis}

R-mode cluster analysis allows us to distinguish four benthic foraminiferal clusters when a cut-off level of 2.4 is applied (Figs. 7 and 9).

Cluster 1 is composed of Elphidium spp. (including $E$. advenum, E. crispum, E. decipiens, E. granosum, E. incertum, E. macellum, and E. margaritaceum), Nonionella turgida, and Quinqueloculina lata. From 738 to $492 \mathrm{~cm}$, 


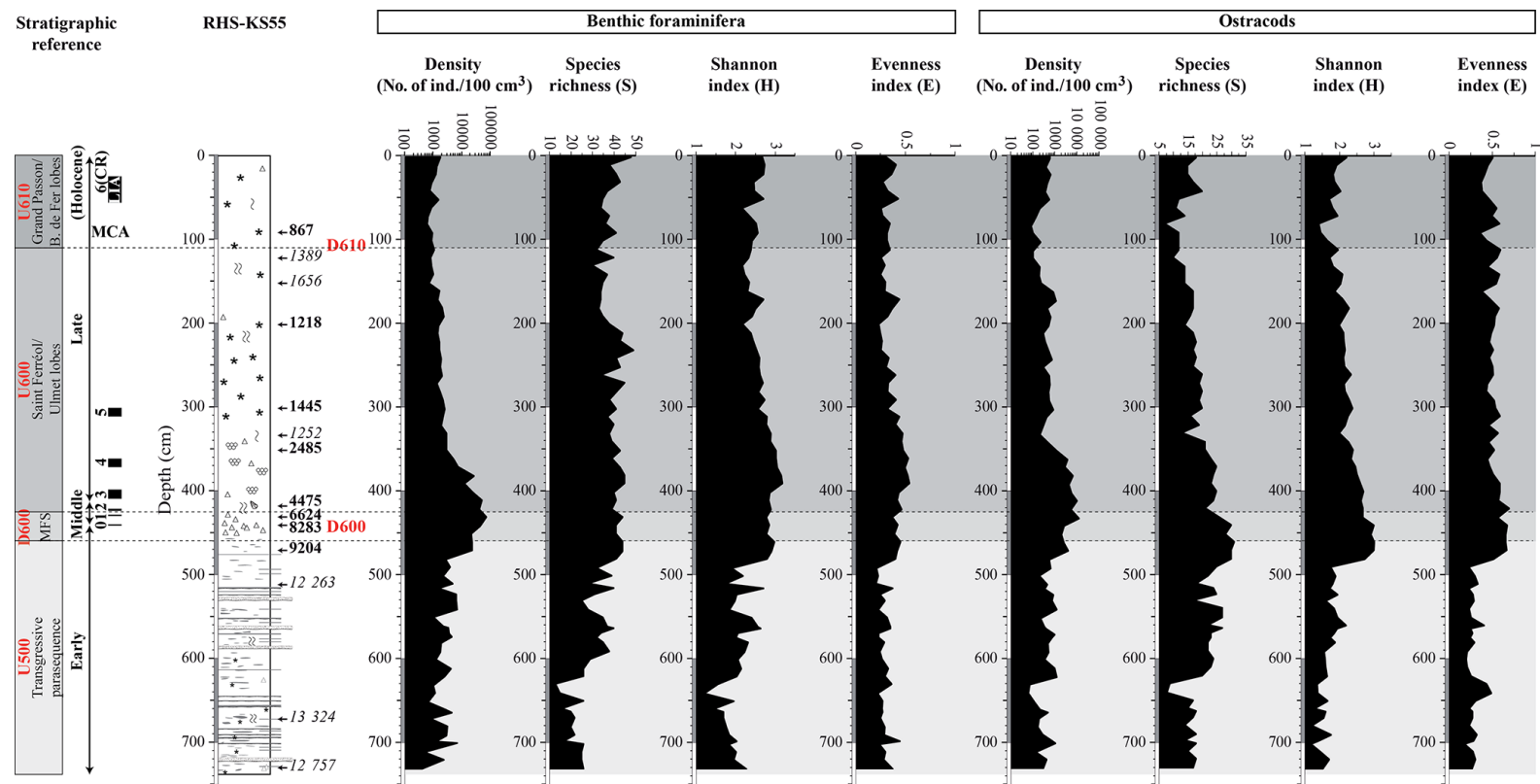

Figure 6. Ecological indices (total abundance per $100 \mathrm{~cm}^{3}$, number of species $(S)$, Shannon $(H)$, and evenness $(E)$ index) describing benthic foraminiferal and ostracod populations. Correlations with seismic units and discontinuities are shown on the left side of the figure. The corresponding positions of seismic units and discontinuities (U500, U600, U610, D600, and D610) are also reported on the plots (gray bands and dashed lines). Black rectangles on the left side of the figure represent the most significant periods of climate deterioration (i.e., cold relapses (CRs)) during the Holocene.
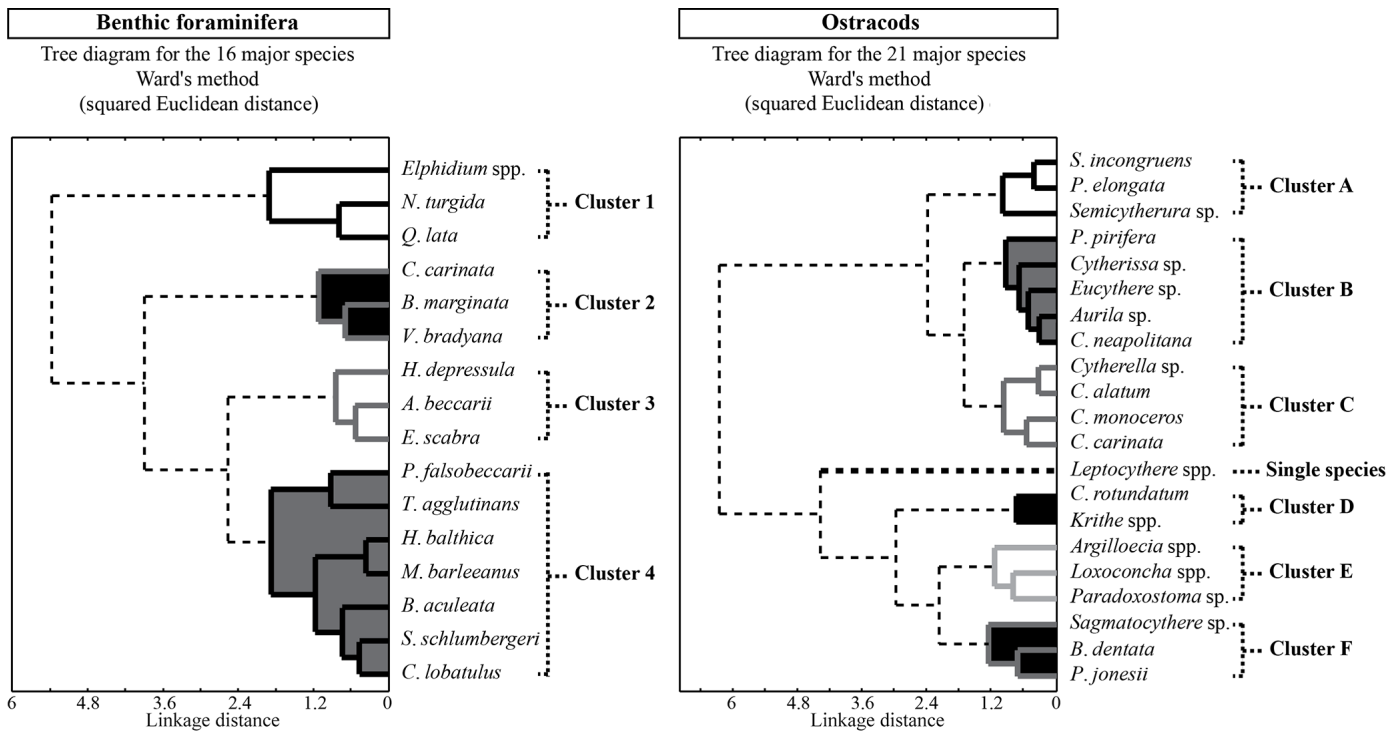

Figure 7. R-mode cluster analyses of the 16 major (more than $5 \%$ in at least one sample) benthic foraminiferal species, and of the 21 major ostracod species according to Ward's method, based on standardized percentages pi of these species.

Cluster 1 dominates strongly with abundances oscillating between ca. 58 and $91 \%$. The contribution of Cluster 1 drops to ca. $15 \%$ at $472 \mathrm{~cm}$. It has a minimal contribution along the uppermost $472 \mathrm{~cm}$ of the core, and especially between 342 and $62 \mathrm{~cm}$, where it exhibits values $<10 \%$.
Cluster 2 is constituted by Cassidulina carinata, Bulimina marginata, and Valvulineria bradyana. It is characterized by a low contribution (less than $10 \%$ ) from 738 to $492 \mathrm{~cm}$. It increases progressively from ca. 15 to $72 \%$ between 482 and $202 \mathrm{~cm}$ and remains quite constant along the uppermost 


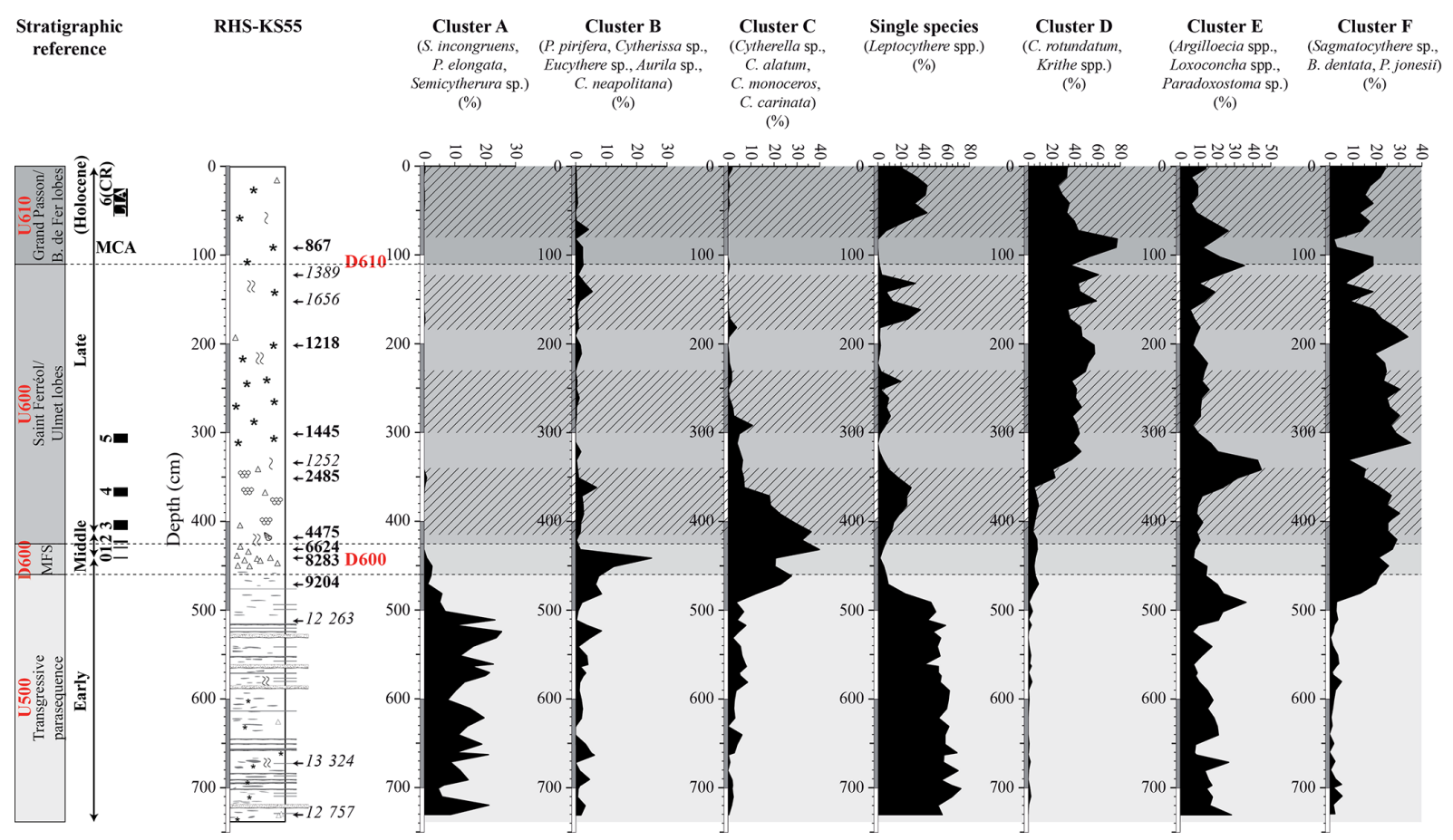

Figure 8. Cumulative percentages of taxa composing the defined ostracod clusters along core RHSKS55. Correlations with seismic units and discontinuities are shown on the left side of the figure. The corresponding positions of seismic units and discontinuities (U500, U600, U610, D600, and D610) are also reported on the plots (gray bands and dashed lines). Holocene cold relapses (CRs) are also indicated on the $y$ axis by the black rectangles (left side of the figure). Periods of increased fluvial discharge are highlighted by peaks in Leptocythere (hatched rectangles). These periods of intensified runoffs correlate to the $2.8 \mathrm{ka}$ event (i.e., CR4) and the LIA (i.e., CR6). Two periods of regional climate deterioration are also observed at 1.3 and $1.1 \mathrm{kacal}$. BP. Conversely, the Migration Period Cooling (i.e., CR5) and the Medieval Climate Anomaly (MCA) correspond to periods of increased dryness.

$192 \mathrm{~cm}$ of the core, with values oscillating between ca. 50 and $72 \%$.

Cluster 3 is made of Haynesina depressula, Ammonia beccarii, and Eggerella scabra. It has a low contribution $(<15 \%)$ through the core RHS-KS55. From 738 to $492 \mathrm{~cm}$, it exhibits relatively erratic values, and three peaks of ca. 12, 5, and $6 \%$ are observed at 699,632 , and $532 \mathrm{~cm}$, respectively. Cluster 3 has a minimal contribution $(<1 \%)$ between 482 and $342 \mathrm{~cm}$ and increases slightly from 332 to $162 \mathrm{~cm}$. From 162 to $82 \mathrm{~cm}$, it increases progressively to reach a value of ca. $9 \%$. Cluster 3 decreases again between 82 and $32 \mathrm{~cm}$ and increases slightly along the uppermost $32 \mathrm{~cm}$ of the core.

Cluster 4 is constituted by Pseudoeponides falsobeccarii, Textularia agglutinans, Hyalinea balthica, Melonis barleeanus, Bulimina aculeata, Sigmoilopsis schlumbergeri, and Cibicides lobatulus. It shows a low contribution from 738 to $492 \mathrm{~cm}$, with erratic values ranging from ca. 5 to $22 \%$. It increases strongly between 482 and $402 \mathrm{~cm}$, where values of ca. $55 \%$ are reached. From 402 to $292 \mathrm{~cm}$, Cluster 4 decreases progressively. It remains quite constant along the uppermost $292 \mathrm{~cm}$ of the core, with values oscillating between ca. 13 and $25 \%$.

\section{Discussion}

\subsection{Benthic meiofauna reworking processes in subaqueous deltaic environment}

In subaqueous deltaic environments, reworking processes appear to be common within transgressive deposits (Cattaneo and Steel, 2003). In the Rhône subaqueous delta, transgressive deposits consist of tempestite deposits (seismic unit U500), which are the result of regular occurrence of highenergy hydrodynamic processes (including combined storm and flood events; Fanget et al., 2014). These processes regularly winnowed the seafloor and generate erosion, reworking, and transport of sediments. Thus, it is likely that benthic calcareous meiofauna are reworked from older deposits into modern deposits having the same faunal assemblages (Cearreta and Murray, 2000). These reworked benthic meiofauna cannot be considered as in situ, but it appears impossible to distinguish them from the unreworked modern tests and carapaces. This will directly affect AMS dating with measured ages older than true ages, as observed within the transgressive seismic unit U500. Such phenomena have been observed in Denmark (Heier-Nielsen et al., 1995) and Spain (Cearreta 
and Murray, 2000), and these highlight the difficulty to obtain reliable AMS dates from high-energy transgressive deposits.

Within the most recent prograding units of the highstand systems tract ( 4.5 to $0.3 \mathrm{kacal}$. BP in the present study), we also observe the regular occurrence of reworking and transport of benthic meiofauna. Reworking processes are regularly encountered in shallow-water environments (e.g., Frenzel and Boomer, 2005; Loureiro et al., 2009; Fanget et al., 2013a). Conversely to the transgressive systems tract, reworked benthic meiofauna are easier to identify since they originate from shallow-water environments and deposit into deeper settings. Reworking processes in AMS dating are thus considered as less important and problematic in the highstand systems tract. It is likely than these allochthonous benthic meiofauna are transported and redeposited further offshore within the river plume during periods of increased river discharge (Fanget et al., 2013a). Thus, it can be relevant to use allochthonous meiofauna as biomarkers for a better understanding of transport and reworking processes (Cronin, 1983; van Harten, 1986; Zhou and Zhao, 1999; Fanget et al., 2013a; Angue Minto'o et al., 2015) and to study paleo-hydrology. The distribution pattern of reworked benthic meiofauna through highstand deposits is likely to reflect hydrological fluctuations in the past (see Sect. 5.3).

\subsection{Record of Holocene sea-level rise and Rhône delta evolution}

Seismic stratigraphy, sedimentological (including clay minerals) and benthic meiofauna data described in the previous section (Sect. 4) allow the subdivision of the studied core into three main intervals. These intervals fairly match the tripartite subdivision of the Holocene (Walker et al., 2012; Wanner et al., 2014) and might be linked to the Holocene sea-level history as well as the Rhône deltaic system evolution.

\subsubsection{Interval 1 (ca. 10.5-8.3 ka cal. BP)}

This interval encompasses most of the early Holocene. The age of the bottom of the core up to ca. $460 \mathrm{~cm}$ cannot be dated precisely because it corresponds to a transgressive parasequence (seismic unit U500, Fig. 2) that formed in a context of shallow-marine environment. Based on the age of the underlying deposits (i.e., the ERDC, seismic unit U400) and on ${ }^{14} \mathrm{C}$ dates, this interval was deposited between ca. 10.5 and $8.3 \mathrm{ka}$ cal. BP (i.e., the early Holocene; Walker et al., 2012). Tempestite (storm-induced) deposits, which are commonly found in lower to middle shoreface environments during periods of storm decelerating flows (Myrow, 1992; Myrow and Southard, 1996; Pérez-López and Pérez-Valera, 2012), characterize this interval (Fig. 4). The intercalation of fine clay and silt layers suggests that these deposits are distal tempestites (i.e., turbidite-like deposited below the storm wave base; Myrow, 1992; Pérez-López and Pérez-Valera, 2012). This facies is interpreted to correspond to an hydrodynamic regime resulting from the combination of E-SE storm waves and flood events (i.e., "wet storms" of Guillén et al., 2006), which regularly winnow the seafloor (Fanget et al., 2014). Tempestite deposits mainly contain foraminifera belonging to Cluster 1 (Elphidium spp., N. turgida, Q. lata) and ostracods belonging to Cluster A ( $S$. incongruens, P. elongata, Semicytherura sp.), as well as to the genus Leptocythere (Figs. 8 and 9). Benthic foraminiferal species, like $N$. turgida, are typical of shallow prodeltaic environment enriched in organic matter of continental origin (e.g., Barmawidjaja et al., 1992; De Rijk et al., 2000; Diz and Francés, 2008; Van der Zwaan and Jorissen, 1991). Elphidium spp. and $Q$. lata are commonly reported in sandy silty substrates subject to strong hydrodynamic processes (e.g., Donnici and Serandrei Barbero, 2002; Jorissen, 1988; Rossi and Vaiani, 2008; Sgarrella and Moncharmont Zei, 1993). Similar observations are described in the modern Rhône subaqueous delta (Goineau et al., 2011, 2015; Mojtahid et al., 2009). Similarly, ostracods content of Cluster A are represented by littoral to sublittoral/phytal marine forms (e.g., Bonaduce et al., 1975; Cabral et al., 2006; Carbonel, 1980; Peypouquet and Nachite, 1984; Zaïbi et al., 2012). The genus Leptocythere is commonly found in brackish and shallow-water environments, and many Leptocythere are known to be euryhaline species (e.g., Anadon et al., 2002; Boomer and Eisenhauer, 2002; Carbonel, 1973, 1980; Frenzel and Boomer, 2005; Gliozzi et al., 2005; Van Morkhoven, 1963).

According to paleoenvironmental reconstruction based on benthic meiofauna from core RHS-KS55, the early Holocene is characterized, in the Rhône subaqueous delta, by highenergy hydrodynamic processes and significant organic matter input of continental origin typical of shallow infra-littoral setting. This interpretation is in agreement with the occurrence of tempestite deposits, as well as the global estimates of sea-level rise during the early Holocene (e.g., Bard et al., 1996; Fairbanks, 1989; Smith et al., 2011). Based on the sealevel curve of Stanford et al. (2011), the base of the core (estimated at ca. $10.5 \mathrm{kacal}$. BP) corresponds to a sea level of ca. $50 \mathrm{~m}$ below its present-day position. Due to the location of core RHS-KS55 at a water depth of $67 \mathrm{~m}$ and its length of $7.38 \mathrm{~m}$, a paleo-water depth of ca. $24 \mathrm{~m}$ can be estimated at the base of the core (subsidence and compaction being considered as negligible). At the top of the tempestite facies (i.e., at ca. $460 \mathrm{~cm}$ ), which is dated at ca. $9.2 \mathrm{ka}$ cal. BP, a paleo-water depth of ca. $52 \mathrm{~m}$ is estimated. Thus, the resulting rate of sea-level rise within this interval $(738-460 \mathrm{~cm})$ is ca. $20 \mathrm{~mm} \mathrm{yr}^{-1}$. This value matches the one found by Stanford et al. (2011) for the early Holocene. Thus, we consider that tempestite deposits, preserved within this transgressive interval (seismic unit U500), are formed at water depth ranging from ca. 20 to $50 \mathrm{~m}$. In the Rhône subaqueous delta, we consider the tempestite facies as a relatively good paleobathymetric marker and we have been able to correlate it over a large prodelta area (see cores RHS-KS40, RHS-KS22, and RHS-KS39 in Fanget et al., 2014). 


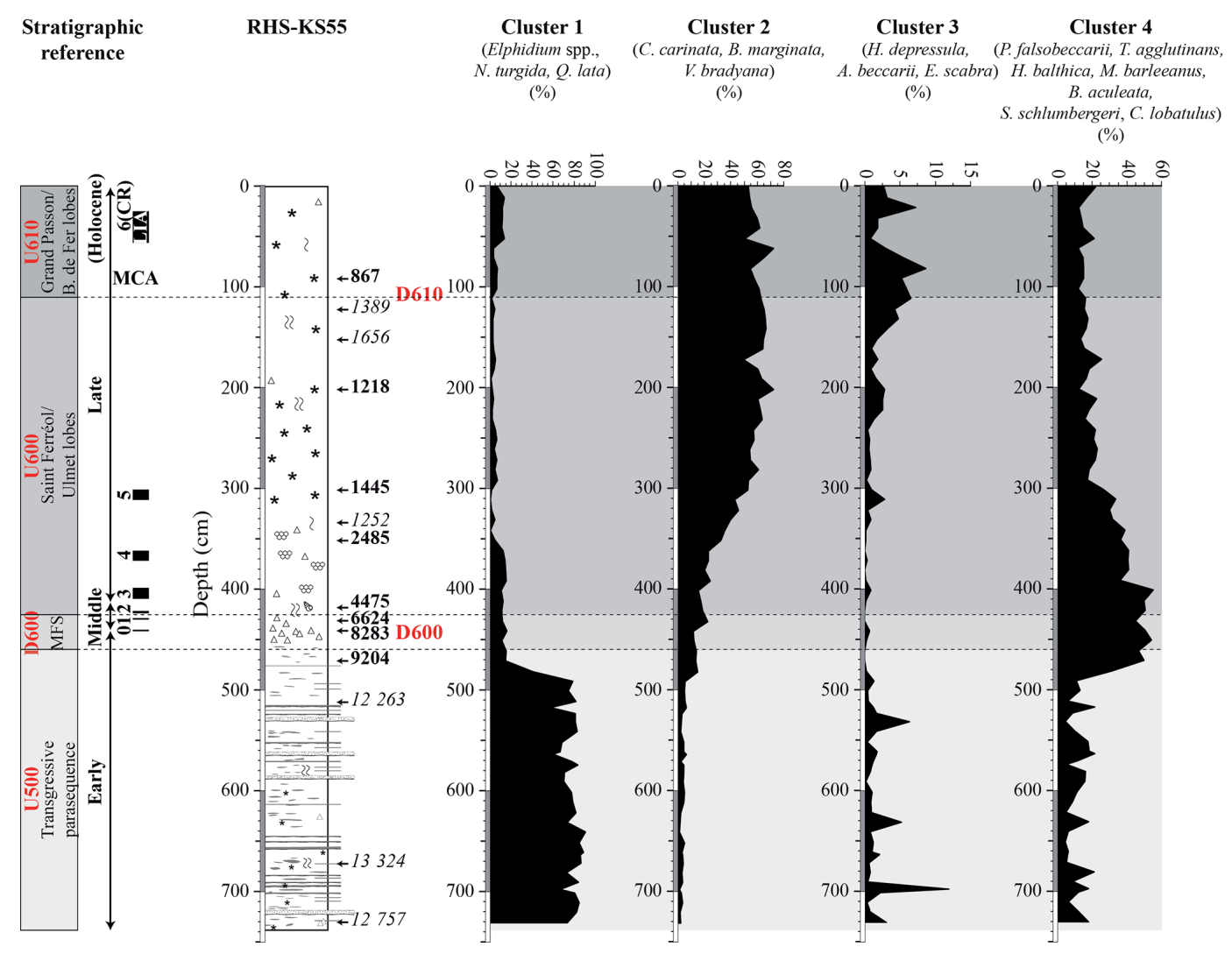

Figure 9. Cumulative percentages of taxa composing the defined benthic foraminiferal clusters along core RHS-KS55. Correlations with seismic units and discontinuities are shown on the left side of the figure. The corresponding positions of seismic units and discontinuities (U500, U600, U610, D600, and D610) are also reported on the plots (gray bands and dashed lines). Holocene cold relapses (CRs) are also indicated on the $y$ axis by the black rectangles (left side of the figure).

\subsubsection{Interval 2 (ca. 8.3-4.5 ka cal. BP)}

The interval between 460 and $430 \mathrm{~cm}$ corresponds to a period ranging from ca. 8.3 to $4.5 \mathrm{kacal}$. BP (i.e., the middle Holocene, Fig. 3), when the Rhône outlet(s) was situated 10 to $30 \mathrm{~km}$ landward from the modern shoreline. Considering the resolution of our seismic data (in the order of ca. $0.5 \mathrm{~m}$ ), it corresponds to the position of the MFS (surface D600, Fig. 2) that marks the transition between retrogradation and progradation. Very low sediment accumulation (ca. $0.01 \mathrm{~cm} \mathrm{yr}^{-1}$, Fig. 4), abundant shell concentration, and very rich microfossil content (up to $\sim 13000$ ostracods $/ 100 \mathrm{~cm}^{3}$ and $\sim 75000$ foraminifera $/ 100 \mathrm{~cm}^{3}$, Fig. 6) indicate sediment starvation within this condensed section which separates transgressive (below) from regressive (above) deposits. This condensed section consists of a silty clay matrix incorporating coarse-grained sediments with reworked shoreface material and shell hash. Clay mineralogy assemblages indicate a clear change in clay mineralogy proportions with a significant decrease in illite content (from 80 to $60 \%$ ) and a sharp increase in smectite content (from 0 to $20 \%$; Fig. 5). Benthic foraminifera belonging to Cluster 4 (P. falsobeccarii, T. agglutinans, $H$. balthica, M. barleeanus, B. aculeata,
S. schlumbergeri, C. lobatulus), and ostracods belonging to Cluster B (P. pirifera, Cytherissa sp., Eucythere sp., Aurila sp., and $C$. neapolitana), Cluster C (Cytherella sp., $C$. alatum, C. monoceros, and C. carinata), and Cluster F (Sagmatocythere sp., B. dentata, and $P$. jonesii) are dominant within this interval (Figs. 8 and 9). Except for C. lobatulus, which is preferentially found in a high-energy shallowwater setting (e.g., Bartels-Jónsdóttir et al., 2006; Javaux and Scott, 2003; Milker et al., 2011; Murray, 2006), foraminifera assemblage is mainly composed of species thriving under a stable environment characterized by marine-derived organic matter input and well-oxygenated sediments (e.g., De Rijk et al., 2000; Debenay and Redois, 1997; Fontanier et al., 2008; Goineau, 2011; Goineau et al., 2011, 2015; Mendes et al., 2004; Mojtahid et al., 2009). Clusters B and F are mainly composed of shallow infra-littoral ostracods (e.g., Bonaduce et al., 1975; Frenzel and Boomer, 2005; Guernet et al., 2003; Ruiz et al., 1997; Zaïbi et al., 2012), whereas Cluster C is primarily made of circa-littoral and epi-bathyal species (e.g., Bonaduce et al., 1975; El Hmaidi et al., 2010; Yamaguchi and Norris, 2012). 
The middle Holocene condensed section is very well identified thanks to benthic microfossils indicating mixed assemblages belonging to diverse environments, from infra-littoral to epi-bathyal settings. Shallow-water species highlight incorporation of the previous shoreface and delta mouth sediments that were left in situ during the transgressive submersion. Circa-littoral and epi-bathyal species indicate an abrupt increase in water depth (peak of transgression) and mark the time of maximum landward shift of the shoreline.

\subsubsection{Interval 3 (ca. 4.5-0.3 ka cal. BP)}

The most recent interval (from $430 \mathrm{~cm}$ to the top of core) corresponds to seismic units U600 and U610 (Fig. 2), which formed during the late Holocene a series of regressive deltaic lobes that make up the highstand systems tract in the sequence stratigraphic terminology. They consist of finegrained prodeltaic deposits and are related to the activity of the St Ferréol and Ulmet distributaries (seismic unit U600), as well as to the synchronous, and thus successive, activity of the Grand Passon and Bras de Fer channels (seismic unit U610) (Fanget et al., 2014). At the core site, clay minerals are dominated by illite, as elsewhere in the Rhône prodelta (Chamley, 1971). Indeed, the Rhône River, receiving its detrital material primarily from the Alps, is particularly rich in illite, associated with some chlorite (Chamley, 1971) that tends to be trapped in sandy sediments during deposition (Chamley, 1971; Giresse et al., 2004). Both minerals represent the relative contribution of physical weathering to sedimentation, since they are resistant to degradation and transport (Chamley, 1971). Relative contents of illite are changing simultaneously with changes in sedimentary facies and activity of different distributaries (Fig. 5). Smectite content is low as a whole but higher than within underlying intervals when sea level was lower. The onset of seaward progradation of the Rhône deltaic lobes corresponds, by definition, to the age of deposits situated immediately above the condensed section. This age is ca. $4.5 \mathrm{ka}$ cal. BP according to the age model. It corresponds to a marked increase in smectite content. It also corresponds to a marked increase in benthic foraminifera belonging to Cluster 2 (C. carinata, B. marginata, and $V$. bradyana) and ostracods belonging to cluster D (C. rotundatum and Krithe spp.) (Figs. 8 and 9). Foraminifera assemblage is constituted by typical species living in the distal part of the Rhône prodelta, with fine-grained sediments enriched in both terrestrial and marine organic matter (Goineau et al., 2011, 2015; Kruit, 1955; Mojtahid et al., 2009). They are also reported as opportunistic species which respond quickly to fresh phytodetritus input by higher reproduction (De Rijk et al., 2000; Fontanier et al., 2003; Goineau et al., 2011; Jorissen, 1987). Ostracods content of Cluster D is known as common assemblage of circa-littoral to epi-bathyal environments (Bonaduce et al., 1975; Coles et al., 1994; Cronin et al., 1999; Didié et al., 2002; Yamaguchi and Norris, 2012). In the Rhône subaqueous delta, we hypothesize that these species can be tolerant to moderate river influence (Fanget et al., 2013b). At the core site, strong decreases in Cluster 1 and Cluster B (shallow infra-littoral species), as well as increases in Cluster 2 and Cluster D, reveal the establishment of prodeltaic conditions since $4.5 \mathrm{ka}$ cal. BP (Figs. 8 and 9). More precisely, they correspond to the progradation of the St Ferréol and Ulmet lobes. A similar pattern is identified on boreholes in the Rhône delta plain, where the onset of prodeltaic sedimentation is marked by the dominance of $V$. bradyana around $4 \mathrm{kacal}$. BP (Amorosi et al., 2013).

Within Interval 3 , we note also the presence of benthic foraminifera belonging to Cluster 3 ( $H$. depressula, A. beccarii, E. scabra), and ostracods belonging to the genus Leptocythere and to Cluster E and F (Figs. 8 and 9). The vertical pattern of these ostracods in this interval will be discussed in further details in the next section (5.3). Foraminifera constituting Cluster 3 are typical of very shallow-water environments, and E. scabra is notably known to be adapted to thrive in organic-matter-enriched and hypoxic sediments (Diz and Francés, 2008; Donnici and Serandrei Barbero, 2002; Jorissen, 1987; Mendes et al., 2004). This assemblage increases in the uppermost $300 \mathrm{~cm}$ of the core, in concomitance with increased hydrotroilite content. Authigenic minerals generated by sulfate reduction (hydrotroilite) can be related both to high sedimentation rate (as observed in the core), leading to reducing conditions, and to high organic matter supply. These observations suggest increased river influence that can be linked to the progressive progradation of Rhône delta and to the beginning of the Bras de Fer and Grand Passon channels' activity, located in front of the studied core.

\subsection{Record of Holocene cold events (CRs)}

Ostracods belonging to Clusters E and F, and especially to the genus Leptocythere, show well-marked peaks within highstand prodeltaic deposits (Fig. 8). As previously described, the genus Leptocythere is widely distributed in brackish and shallow marine water environments (Anadon et al., 2002; Boomer and Eisenhauer, 2002; Carbonel, 1973, 1980; Frenzel and Boomer, 2005; Gliozzi et al., 2005; Van Morkhoven, 1963). In the Po delta, the occurrence of Leptocythere sp. is notably related to local increase in fluvial influence (Rossi, 2009), and in the Rhône delta, few valves of Leptocythere are encountered in restricted environmental areas characterized by estuarine conditions (Amorosi et al., 2013). Thus, the distribution pattern of Leptocythere through the highstand deposits would reflect hydrological fluctuations. During the Holocene, high fluctuations in precipitations are recorded, notably during the CRs (Mayewski et al., 2004; Wanner et al., 2014). In Europe, these CRs (or at least CR0, i.e., the 8.2 ka event, and CR6, i.e., the LIA) are characterized by intensified rainfalls (Arnaud et al., 2012; Magny et al., 2010; Magny and Begeot, 2004).

Two intervals of increased occurrence of Leptocythere (and therefore increased rainfall) are identified between 
ca. 400 and 350, and ca. 70 and $0 \mathrm{~cm}$ (Fig. 8). They correspond to ages between ca. 4.0 and 2.2 and between 0.6 and $0.2 \mathrm{ka}$ cal. BP, respectively. These intervals are close to CR4 and CR6 (i.e., the LIA) that are dated between ca. 3.1 and 2.8 and ca. 0.65 and $0.15 \mathrm{ka}$ cal. BP, respectively (Wanner et al., 2014). The hypothesis of increased rainfall and river runoff, in the Rhône watershed, during the cooler late Holocene is supported, at least for the LIA, by the observed advance of the Rhône Glacier (Goehring et al., 2011), the high level in Lake Bourget (France) (Arnaud et al., 2012), higher soil erosion in the French Pre-Alps (Simonneau et al., 2013), increased detritism in the Rhône delta plain (Bruneton et al., 2001; Provansal et al., 2003), and increased Rhône River floods (Pichard, 1995). In contrast, CR5, the so-called Migration Period Cooling, is not characterized by any increase in Leptocythere, suggesting drier conditions in the Rhône watershed compared to CR4 and CR6.

The signature of CR0 (the $8.2 \mathrm{ka}$ event), CR1, CR2, and CR3 is difficult to discriminate since the events are incorporated within a condensed section with very low accumulation rate (Fig. 8).

On the other hand, we also notice that two other periods of increased Leptocythere are recorded between ca. 300 and $230 \mathrm{~cm}$ and between ca. 180 and $120 \mathrm{~cm}$, i.e., between ca. 1.4 and $1.3 \mathrm{kacal}$. BP and ca. 1.2 and $1.0 \mathrm{kacal}$. BP (Fig. 8). These periods are not related to global events (CR-like) but might correlate to periods of regional climate deterioration as attested by a high level of Lake Bourget (Arnaud et al., 2012), as well as by periods of increased detritism in the Rhône delta plain (Provansal et al., 2003).

Conversely, a strong decrease in Leptocythere is observed from 120 to $80 \mathrm{~cm}$ (Fig. 8). This suggests drier conditions during this interval, which corresponds to the MCA (ca. AD 950-1250). In the Northern Hemisphere, the MCA is generally described as a warm period characterized by intense dryness. In the Mediterranean, several studies have highlighted drier conditions during this event (e.g., Wassenburg et al., 2013; Martinez-Ruiz et al., 2015; Bassetti et al., 2016). The same signature is also observed in the Alps and the Rhône watershed, with periods of low lake level and low flood frequency, respectively (e.g., Magny, 2004; Wilhelm et al., 2016). Thus, the hypothesis of increased drought at the studied site during the MCA fits well with regional and local observations.

Within the late Holocene interval, the distribution pattern of Cluster E is slightly offset of the single species Leptocythere (Fig. 8). This cluster is constituted by the shallow infra-littoral Paradoxostoma and Loxoconcha species (Bonaduce et al., 1975; El Hmaidi et al., 2010) and by the epibathyal Argilloecia species. Argilloecia sp., in the Rhône subaqueous delta, appears to be tolerant to fluvial influence and potentially responds to organic matter supply (Fanget et al., 2013b). Nevertheless, an increase in Cluster E is not recorded within the periods characterized by higher river supply such as the CR4 and CR6 (i.e., the LIA) but slightly after these periods. This possibly indicates that Leptocythere is a better competitor during periods of increased detritism and fluvial discharge.

\section{Conclusion}

Our study shows that some environmental and sea-level changes during the Holocene can be clearly depicted from sedimentological and benthic meiofauna proxies.

During the early Holocene (11.7 to 7-8 ka cal. BP), sealevel rise led to the deposition of tempestite sediments that contain shallow infra-littoral benthic meiofauna. These deposits are thought to be formed between ca. 20 and $50 \mathrm{~m}$ water depth, and we believe that this feature can be used as a good regional scale paleobathymetric marker.

The middle Holocene (7-8 to 4-5 ka cal. BP) corresponds to a phase of very low sedimentation at the core site, resulting in the formation of a condensed section (i.e., the MFS in sequence stratigraphic terminology) reflecting the further landward position of the shoreline and Rhône outlet(s). This condensed section contains reworked shoreface material within a fine-grained matrix. It displays mixed faunal assemblages, ranging from infra-littoral to epi-bathyal environments, which are the result of erosion processes that occurred during the period of transgressive submersion and, thus, mark the peak of transgression and the subsequent sediment starvation.

Following the transgressive maximum, the late Holocene (4-5 ka cal. BP to 19th century AD) sediment deposits are influenced by a combination of allocyclic and autocyclic factors. The progressive shoreline progradation and prodeltaic lobes' switching is characterized by changes in clay mineralogy content, by the setting-up of benthic meiofauna adapted to thrive in the distal part of the Rhône River influence (i.e., distal St Ferréol and Ulmet lobes), and by the presence of very shallow-water species (i.e., proximal Grand Passon and Bras de Fer lobes).

Within the late Holocene deposits, ostracod assemblages emphasize fluctuations in the Rhône River hydrological activity. In particular, the occurrence of the ostracod genus Leptocythere highlights periods of increased fluvial discharge. These periods of intensified runoffs can be attributed to the $2.8 \mathrm{ka}$ event (CR4) and the Little Ice Age (CR6) that are known to be at the origin of regional climate deterioration in western Europe, as well as periods of regional climate deterioration at ca. 1.3 and $1.1 \mathrm{ka}$ cal. BP. In contrast, the signatures of the early and middle Holocene cold relapses are difficult to explore in the Rhône subaqueous delta since they correspond respectively to (a) a phase of rapid sea-level rise at the origin of shoreline reworking and deposition of tempestite and (b) a period of very low sedimentation at the core site resulting in a condensed interval with low temporal resolution.

Finally, our study demonstrates that prodeltas may provide interesting expanded archives of climate changes at 
the land/sea interface, with accumulation rates reaching $0.4 \mathrm{~m} \mathrm{yr}^{-1}$. On the other hand, such resolution can be achieved at one single site for only short time intervals, since depot centers migrate rapidly as a consequence of sea-level changes, high sediment fluxes, and lateral shifting of delta lobes. This highlights the need for acquiring series of long cores/boreholes, parallel and orthogonal to deltaic systems.

\section{Data availability}

For access to the proxy data, the respective authors should be contacted personally.

Acknowledgements. Core RHS-KS55 was collected during the RHOSOS cruise (2008) on board R/V Le Suroit. We thank the captain and crew of this cruise together with the Genavir technical staff and the scientific parties. Special thanks are due to Bernard Dennielou (IFREMER, Brest) for his commitment at sea and during the processing of the data in the laboratory. We thank the Laboratoire de Mesure du Carbone 14, UMS 2572, ARTEMIS in Saclay for ${ }^{14} \mathrm{C}$ measurements by SMA in the frame of the National Service to CEA, CNRS, IRD, IRSN, and Ministère de la Culture et de la Communication. This work was partly supported by the CNRS-INSU "Mistrals-Paleomex". We are grateful to Bertil Hebert (CEFREM, University of Perpignan), Gilbert Floch, Angélique Roubi, and Mickaël Rovere (IFREMER, Brest) for their technical support. We would like to thank A. Amorosi and L. Goisan for their comments and suggestions that helped to improve the manuscript. S. Luening is also thanked for commenting on the manuscript during the open discussion.

Edited by: N. Combourieu Nebout

Reviewed by: A. Amorosi and L. Giosan

\section{References}

Alley, R. B., Mayewski, P. A., Sowers, T., Stuiver, M., Taylor, K. C., and Clark, P. U.: Holocene climatic instability: A prominent, widespread event 8200 yr ago, Geology, 25, 483-486, 1997.

Aloïsi, J. C., Auffret, G. A., Auffret, J. P., Barusseau, J. P., Hommeril, P., Larsonneur, C., and Monaco, A.: Essai de modélisation de la sédimentation actuelle sur les plateaux continentaux français, B. Soc. Géol. Fr., 19, 183-195, 1977.

Amorosi, A., Dinelli, E., Rossi, V., Vaiani, S. C., and Sacchetto, M.: Late Quaternary palaeoenvironmental evolution of the Adriatic coastal plain and the onset of Po River Delta, Palaeogeogr. Palaeocl., 268, 80-90, 2008.

Amorosi, A., Rossi, V., and Vella, C.: Stepwise post-glacial transgression in the Rhône Delta area as revealed by high-resolution core data, Palaeogeogr. Palaeocl., 374, 314-326, 2013.

Anadon, P., Gliozzi, E., and Mazzini, I.: Paleoenvironmental reconstruction of marginal marine environments from combined paleogical and geochemical analyses on ostracods, in: The Ostracoda: Apllications in Quaternary Research, edited by: Holmes, J. A. and Chivas, A. R., American geophysical Union, Washington, DC, 2002.
Angue Minto'o, C. M., Bassetti, M. A., Morigi, C., Ducassou, E., Toucanne, S., Jouet, G., and Mudler, T.: Levantine intermediate water hydrodynamic and bottom water ventilation in the northern Tyrrhenian Sea over the past 56,000 years: new insights from benthic foraminifera and ostracods, Quatern. Int., 357, 295-313, 2015.

Arnaud-Fassetta, G.: Dynamiques fluviales holocènes dans le delta du Rhône, PhD, UFR des Sciences Géographiques, Université de Provence, Aix en Provence, 329 pp., 1998.

Arnaud-Fassetta, G.: Geomorphological records of a flooddominated regime in the Rhône delta (France) between the 1st century and the 2nd century $\mathrm{AD}$. What correlations with the catchment paleohydrology?, Geodin. Acta, 15, 79-92, 2002.

Arnaud, F., Révillon, S., Debret, M., Revel, M., Chapron, E., Jacob, J., Giguet-Covex, C., Poulenard, J., and Magny, M.: Lake Bourget regional erosion patterns reconstruction reveals Holocene NW European Alps soil evolution and paleohydrology, Quaternary Sci. Rev., 51, 81-92, 2012.

Barber, D. C., Dyke, A., Hillaire-Marcel, C., Jennings, A. E., Andrews, J. T., Kerwin, M. W., Bilodeau, G., McNeely, R., Southon, J., Morehead, M. D., and Gagnon, J. M.: Forcing of the cold event of 8,200 years ago by catastrophic drainage of Laurentide lakes, Nature, 400, 344-348, 1999.

Bard, E., Hamelin, B., Arnold, M., Montaggioni, L., Cabioch, G., Faure, G., and Rougerie, F.: Deglacial sea-level record from Tahiti corals and the timing of global meltwater discharge, Nature, 382, 241-244, 1996.

Barmawidjaja, D. M., Jorissen, F. J., Puskaric, S., and van der Zwaan, G. J.: Microhabitat selection by benthic Foraminifera in the northern Adriatic Sea, J. Foramin. Res., 22, 297-317, 1992.

Bartels-Jónsdóttir, H. B., Knudsen, K. L., Abrantes, F., Lebreiro, S., and Eiríksson, J.: Climate variability during the last 2000 years in the Tagus Prodelta, western Iberian Margin: Benthic foraminifera and stable isotopes, Mar. Micropaleontol., 59, 83-103, 2006.

Bassetti, M. A., Berné, S., Jouet, G., Taviani, M., Dennielou, B., Flores, J. A., Gaillot, A., Gelfort, R., Lafuerza, S., and Sultan, N.: The 100-ka and rapid sea level changes recorded by prograding shelf sand bodies in the Gulf of Lions (western Mediterranean Sea), Geochem. Geophy. Geosy., 9, Q11R05, doi:10.1029/2007GC001854, 2008.

Bassetti, M.-A., Berné, S., Sicre, M.-A., Dennielou, B., Alonso, Y., Buscail, R., Jalali, B., Hebert, B., and Menniti, C.: Holocene hydrological changes in the Rhône River (NW Mediterranean) as recorded in the marine mud belt, Clim. Past, 12, 1539-1553, doi:10.5194/cp-12-1539-2016, 2016.

Berné, S., Jouet, G., Bassetti, M. A., Dennielou, B., and Taviani, M.: Late Glacial to Preboreal sea-level rise recorded by the Rhone deltaic system (NW Mediterranean), Mar. Geol., 245, 65-88, 2007.

Bhattacharya, J. P. and Giosan, L.: Wave-influenced deltas: geomorphological implications for facies reconstruction, Sedimentology, 50, 187-210, 2003.

Blaauw, M.: Methods and code for "classical" age-modelling of radiocarbon sequences, Quat. Geochronol., 5, 512-518, 2010.

Bonaduce, G., Ciampo, G., and Masoli, M.: Distribution of Ostracoda in the Adriatic Sea, Pubbl. Staz. Zool. Napoli, 40, 1-148, 1975.

Boomer, I. and Eisenhauer, G.: Ostracod faunas as paleoenvironmental indicators in marginal marine environments, in: The Os- 
tracoda: Applications in quaternary Research, edited by: Holmes, J. A. and Chivas, A. R., American Geophysical Union, Washington, DC, 2002.

Boyer, J., Duvail, C., Le Strat, P., Gensous, B., and Tesson, M.: High resolution stratigraphy and evolution of the Rhone delta plain during Postglacial time, from subsurface drilling data bank, Mar. Geol., 222-223, 267-298, 2005.

Bruneton, H., Arnaud-Fassetta, G., Provansal, M., and Sistach, D.: Geomorphological evidence for fluvial change during the Roman period in the lower Rhone valley (southern France), CATENA, 45, 287-312, 2001.

Cabral, M. C., Freitas, M. C., Andrade, C., and Cruces, A.: Coastal evolution and Holocene ostracods in Melides lagoon (SW Portugal), Mar. Micropaleontol., 60, 181-204, 2006.

Campbell, C. V.: Lamina, laminaset, bed and bedset, Sedimentology, 8, 7-26, 1967.

Carbonel, P.: Les ensembles fauniques d'Ostracodes récents de l'Estuaire de la Gironde, Bulletin de l'Institut de Géologie du Bassin d'Aquitaine, 14, 75-81, 1973.

Carbonel, P.: Les ostracodes et leur intérêt dans la définition des écosystèmes estuariens et de la plateforme continentale. Essais d'application à des domaines anciens, Mémoire de l'Institut de Géologie du Bassin d'Aquitaine, 11, 350 pp., 1980.

Cattaneao, A. and Steel, R. J.: Transgressive deposits: a review of their variability, Earth Sci. Rev., 62, 187-228, 2003.

Cattaneo, A., Correggiari, A., Langone, L., and Trincardi, F.: The late-Holocene Gargano subaqueous delta, Adriatic shelf: Sediment pathways and supply fluctuations, Mar. Geol., 193, 61-91, 2003.

Cearreta, A. and Murray, J. W.: AMS ${ }^{14} \mathrm{C}$ dating of Holocene estuarine deposits: consequences of high-energy and reworked foraminifera, Holocene, 10, 155-159, 2000.

Chambers, F. M., Mauquoy, D., Brain, S. A., Blaauw, M., and Daniell, J. R. G.: Globally synchronous climate change 2800 years ago: Proxy data from peat in South America, Earth Planet. Sc. Lett., 253, 439-444, 2007.

Chamley, H.: Recherches sur la sédimentation argileuses en Méditerranée, Université Aix-Marseille, France, 1971.

Coles, G., Whatley, R., and Moguilevsky, A.: The ostracode genus Krithe from the Tertiary and Quaternary of the North Atlantic, Paleontology, 37, 71-120, 1994.

Cronin, T. M.: Bathyal ostracodes from the Florida-Hatteras slope, the Straits of Florida, and the Blake Plateau, Mar. Micropaleontol., 8, 89-119, 1983.

Cronin, T. M., DeMartino, D. M., Dwyer, G. S., and RodriguezLazaro, J.: Deep-sea ostracode species diversity: response to late Quaternary climate change, Mar. Micropaleontol., 37, 231-249, 1999.

Davis, B. A. S., Brewer, S., Stevenson, A. C., and Guiot, J.: The temperature of Europe during the Holocene reconstructed from pollen data, Quaternary Sci. Rev., 22, 1701-1716, 2003.

Debenay, J.-P. and Redois, F.: Distribution of the twenty seven dominant species of shelf benthic foraminifers on the continental shelf, north of Dakar (Senegal), Mar. Micropaleontol., 29, 237255, 1997.

De Rijk, S., Jorissen, F. J., Rohling, E. J., and Troelstra, S. R.: Organic flux control on bathymetric zonation of Mediterranean benthic foraminifera, Mar. Micropaleontol., 40, 151-166, 2000.
Didié, C., Bauch, H. A., and Helmke, J. P.: Late Quaternary deepsea ostracodes in the polar and subpolar North Atlantic: paleoecological and paleoenvironmental implications, Palaeogeogr. Palaeocl., 184, 195-212, 2002.

Diz, P. and Francés, G.: Distribution of live benthic foraminifera in the Ría de Vigo (NW Spain), Mar. Micropaleontol., 66, 165-191, 2008.

Do Carmo, D. A. and Sanguinetti, Y. T.: Taxonomy and palaeoceanographical significance of the genus Krithe (Ostracoda) in the Brazilian margin, J. Micropalaeontol., 18, 111-123, 1999.

Donnici, S. and Serandrei Barbero, R.: The benthic foraminiferal communities of the northern Adriatic continental shelf, Mar. Micropaleontol., 44, 93-123, 2002.

El Hmaidi, A., El Moumni, B., Nachite, D., Bekkali, R., and Gensous, B.: Distribution et caractéristiques des associations d'ostracodes au Pléistocène supérieur et Holocène au niveau de la marge orientale du détroit de Gibraltar (mer d'Alboran, Maroc), Revue de Micropaléontologie, 53, 17-28, 2010.

Fairbanks, R. G.: A 17,00-year glacio-eustatic sea-level record: influence of glacial melting rates on the Younger Dryas event and deep-ocean circulation, Nature, 342, 637-642, 1989.

Fanget, A. S., Bassetti, M. A., Arnaud, M., Chiffoleau, J. F., Cossa, D., Goineau, A., Fontanier, C., Buscail, R., Jouet, G., Maillet, G. M., Negri, A., Dennielou, B., and Berné, S.: Historical evolution and extreme climate events during the last 400 years on the Rhone prodelta (NW Mediterranean), Mar. Geol., 346, 375-391, 2013a.

Fanget, A. S., Bassetti, M. A., Berné, S., and Arnaud, M.: Epibathyal ostracod assemblage in Holocene Rhone deltaic sediments (Gulf of Lions, NW Mediterranean) and their palaeoecological implications, Revue de Paléobiologie, 32, 589-606, 2013 b.

Fanget, A.-S., Berné, S., Jouet, G., Bassetti, M.-A., Dennielou, B., Maillet, G. M., and Tondut, M.: Impact of relative sea level and rapid climate changes on the architecture and lithofacies of the Holocene Rhone subaqueous delta (Western Mediterranean Sea), Sediment. Geol., 305, 35-53, 2014.

Fontanier, C., Jorissen, F. J., Chaillou, G., David, C., Anschutz, P., and Lafon, V.: Seasonal and interannual variability of benthic foraminiferal faunas at $550 \mathrm{~m}$ depth in the Bay of Biscay, DeepSea Res. Pt. I, 50, 457-494, 2003.

Fontanier, C., Jorissen, F. J., Lansard, B., Mouret, A., Buscail, R., Schmidt, S., Kerhervé, P., Buron, F., Zaragosi, S., Hunault, G., Ernoult, E., Artero, C., Anschutz, P., and Rabouille, C.: Live foraminifera from the open slope between Grand Rhône and Petit Rhône Canyons (Gulf of Lions, NW Mediterranean), Deep-Sea Res. Pt. I, 55, 1532-1553, 2008.

Frenzel, P. and Boomer, I.: The use of ostracods from marginal marine, brackish waters as bioindicators of modern and Quaternary environmental change, Palaeogeogr. Palaeocl., 225, 68-92, 2005.

Frezza, V. and Carboni, M. G.: Distribution of recent foraminiferal assemblages near the Ombrone River mouth (Northern Tyrrhenian Sea, Italy), Revue de Micropaléontologie, 52, 43-66, 2009.

Frigola, J., Canals, M., Cacho, I., Moreno, A., Sierro, F. J., Flores, J. A., Berné, S., Jouet, G., Dennielou, B., Herrera, G., Pasqual, C., Grimalt, J. O., Galavazi, M., and Schneider, R.: A 500 kyr record of global sea-level oscillations in the Gulf of Lion, Mediterranean Sea: new insights into MIS 3 sea-level variability, Clim. Past, 8, 1067-1077, doi:10.5194/cp-8-1067-2012, 2012. 
Galloway, W. E.: Process framework for describing the morphologic and stratigraphic evolution of deltaic depositional systems, in: Deltas, Models for Exploration, edited by: Broussard, M. L., Houston Geological Society, 1975.

Gensous, B. and Tesson, M.: Postglacial deposits of the Rhone shelf: stratigraphic organisation and growth patterns, Comptes Rendus de L'Académie des Sciences - Series IIA - Earth and Planetary Science, 325, 695-701, 1997.

Gensous, B., Williamson, D., and Tesson, M.: Late-Quaternary transgressive and highstand deposits of a deltaic shelf (Rhône delta, France), in: Sequence stratigraphy and facies associations, edited by: Posamentier, H. W., Summerhayes, C. P., Haq, B. A., and Allen, G. P., International Association of Sedimentologists Spec. Pub. 18, Blackwell, Oxford, 1993.

Giresse, P., Wiewiorka, A., and Grabska, D.: Glauconization processes in the Northwestern Mediterranean (Gulf of Lions), Clay Miner., 39, 57-73, 2004.

Gliozzi, E., Rodriguez-Lazaro, J., Nachite, D., Martin-Rubio, M., and Bekkali, R.: An overview of Neogene brackish leptocytherids from Italy and Spain: Biochronological and palaeogeographical implications, Palaeogeogr. Palaeocl., 225, 283-301, 2005.

Goehring, B. M., Schaefer, J. M., Schluechter, C., Lifton, N. A., Finkel, R. C., Jull, A. J. T., Akçar, N., and Alley, R. B.: The Rhone Glacier was smaller than today for most of the Holocene, Geology, 39, 679-682, 2011.

Goineau, A.: Ecologie des foraminifères benthiques dans le prodelta du Rhône. Détermination de bio-indicateurs environnementaux et reconstitution historique d'une anthropisation récente, $\mathrm{PhD}$, Université d'Angers, Angers, 310 pp., 2011.

Goineau, A., Fontanier, C., Jorissen, F. J., Lansard, B., Buscail, R., Mouret, A., Kerhervé, P., Zaragosi, S., Ernoult, E., Artéro, C., Anschutz, P., Metzger, E., and Rabouille, C.: Live (stained) benthic foraminifera from the Rhône prodelta (Gulf of Lion, NW Mediterranean): Environmental controls on a river-dominated shelf, J. Sea Res., 65, 58-75, 2011.

Goineau, A., Fontanier, C., Mojtahid, M., Fanget, A. S., Bassetti, M. A., Berné, S., and Jorissen, F.: Live-dead comparison of benthic foraminiferal faunas from the Rhône prodelta (Gulf of Lions, NW Mediterranean): Development of a proxy for palaeoenvironmental reconstructions, Mar. Micropaleontol., 119, 17-33, 2015.

Guernet, C., Lemeille, F., Sorel, D., Bourdillon, C., Berge-Thierry, C., and Manakou, M.: Les Ostracodes et le Quaternaire d'Aigion (golfe de Corinthe, Grèce), Revue de Micropaléontologie, 46, 73-93, 2003.

Guillén, J., Bourrin, F., Palanques, A., Durrieu de Madron, X., Puig, P., and Buscail, R.: Sediment dynamics during wet and dry storm events on the Tet inner shelf (SW Gulf of Lions), Mar. Geol., 234, 129-142, 2006.

Hammer, O., Harper, D. A. T., and Ryan, P. D.: PAST: paleontological statistics software package for education and data analysis, Palaeontol. Electron., 4, 4-9, 2001.

Hayek, L. E. C. and Buzas, M. A.: Surveying Natural Populations, Columbia University Press, New York, 563 pp., 1997.

Heier-Nielsen, S., Conradsen, K., Heinemeier, J., Knudsen, K. L., Nielsen, H. L., Rud, N., and Sveinbjönsdóttir, A. E.: Radiocarbon dating of shells and foraminifera from the Skagen core, Denmark: evidence of reworking, Radiocarbon, 37, 119-130, 1995.
Ivy-Ochs, S., Kerschner, H., Maisch, M., Christl, M., Kubik, P. W., and Schlüchter, C.: Latest Pleistocene and Holocene glacier variations in the European Alps, Quaternary Sci. Rev., 28, 2137 2149, 2009.

Jalali, B., Sicre, M.-A., Bassetti, M.-A., and Kallel, N.: Holocene climate variability in the North-Western Mediterranean Sea (Gulf of Lions), Clim. Past, 12, 91-101, doi:10.5194/cp-12-91-2016, 2016.

Javaux, E. and Scott, D. B.: Illustration of modern benthic foraminifera from Bermuda and remarks on distribution in other subtropical/tropical areas, Palaeontol. Electron., 6, 29 pp., 2003.

Jorissen, F.: Benthic foraminifera from the Adriatic Sea: principles of phenotypic variation, Utrecht Micropaleontology Bulletin, 37, $1-174,1988$.

Jorissen, F. J.: The distribution of benthic foraminifera in the Adriatic Sea, Mar. Micropaleontol., 12, 21-48, 1987.

Kruit, C.: Sediments of the Rhône delta: Grain Size and Microfauna, Mouton and Co, La Haye, 357-555, 1955.

Labaune, C., Jouet, G., Berné, S., Gensous, B., Tesson, M., and Delpeint, A.: Seismic stratigraphy of the Deglacial deposits of the Rhone prodelta and of the adjacent shelf, Mar. Geol., 222223, 299-311, 2005.

L'Homer, A., Bazile, F., Thommeret, J., and Thommeret, Y.: Principales étapes de l'édification du delta du Rhône de 7000 B.P. à nos jours ; variations du niveau marin, Oceanis, 7, 389-408, 1981.

Liu, J. P., Milliman, J. D., Gao, S., and Cheng, P.: Holocene development of the Yellow River's subaqueous delta, North Yellow Sea, Mar. Geol., 209, 45-67, 2004.

Liu, Z., Colin, C., Trentesaux, A., Blamart, D., Bassinot, F., Siani, G., and Sicre, M.-A.: Erosional history of the eastern Tibetan Plateau since $190 \mathrm{kyr}$ ago: clay mineralogical and geochemical investigations from the southwestern South China Sea, Mar. Geol., 209, 1-18, 2004.

Liu, Z., Berne, S., Saito, Y., Yu, H., Trentesaux, A., Uehara, K., Yin, P., Paul Liu, J., Li, C., Hu, G., and Wang, X.: Internal architecture and mobility of tidal sand ridges in the East China Sea, Cont. Shelf Res., 27, 1820-1834, 2007.

Liu, Z., Tuo, S., Colin, C., Liu, J. T., Huang, C.-Y., Selvaraj, K., Chen, C.-T. A., Zhao, Y., Siringan, F. P., Boulay, S., and Chen, Z.: Detrital fine-grained sediment contribution from Taiwan to the northern South China Sea and its relation to regional ocean circulation, Mar. Geol., 255, 149-155, 2008.

Lofi, J., Rabineau, M., Gorini, C., Berne, S., Clauzon, G., De Clarens, P., Tadeu Dos Reis, A., Mountain, G. S., Ryan, W. B. F., Steckler, M. S., and Fouchet, C.: Plio-Quaternary prograding clinoform wedges of the western Gulf of Lion continental margin (NW Mediterranean) after the Messinian Salinity Crisis, Mar. Geol., 198, 289-317, 2003.

Loureiro, I. M., Cabral, M. C., and Fatela, F.: Marine influence in ostracod assemblages of the Mira River estuary: comparison between lower and mid estuary tidal marsh transects, J. Coastal Res., 56, 1365-1369, 2009.

Magny, M.: Holocene climate variability as reflected by midEuropean lake-level fluctuations and its probable impact on prehistoric human settlements, Quatern. Int., 113, 65-79, 2004.

Magny, M. and Begeot, C.: Hydrological changes in the European midlatitudes associated with freshwater outbursts from Lake Agassiz during the Younger Dryas event and the early Holocene, Quaternary Res., 61, 181-192, 2004. 
Magny, M., Bégeot, C., Guiot, J., and Peyron, O.: Contrasting patterns of hydrological changes in Europe in response to Holocene climate cooling phases, Quaternary Sci. Rev., 22, 1589-1596, 2003.

Magny, M. and Haas, J. N.: A major widespread climatic change around $5300 \mathrm{cal}$. yr BP at the time of the Alpine Iceman, J. Quaternary Sci., 19, 423-430, 2004.

Magny, M., Arnaud, F., Holzhauser, H., Chapron, E., Debret, M., Desmet, M., Leroux, A., Millet, L., Revel, M., and Vannière, B.: Solar and proxy-sensitivity imprints on paleohydrological records for the last millennium in west-central Europe, Quaternary Res., 73, 173-179, 2010.

Magny, M., Combourieu-Nebout, N., de Beaulieu, J. L., BoutRoumazeilles, V., Colombaroli, D., Desprat, S., Francke, A., Joannin, S., Ortu, E., Peyron, O., Revel, M., Sadori, L., Siani, G., Sicre, M. A., Samartin, S., Simonneau, A., Tinner, W., Vannière, B., Wagner, B., Zanchetta, G., Anselmetti, F., Brugiapaglia, E., Chapron, E., Debret, M., Desmet, M., Didier, J., Essallami, L., Galop, D., Gilli, A., Haas, J. N., Kallel, N., Millet, L., Stock, A., Turon, J. L., and Wirth, S.: North-south palaeohydrological contrasts in the central Mediterranean during the Holocene: tentative synthesis and working hypotheses, Clim. Past, 9, 20432071, doi:10.5194/cp-9-2043-2013, 2013.

Martinez-Ruiz, F., Kastner, M., Gallego-Torres, D., RodrigoGámiz, M., Nieto-Moreno, V., and Ortega-Huertas, M.: Paleoclimate and paleoceanography over the past $20,000 \mathrm{yr}$ in the Mediterranean Sea Basins as indicated by sediment elemental proxies, Quaternary Sci. Rev., 107, 25-46, 2015.

Mayewski, P. A., Rohling, E. E., Curt Stager, J., Karlén, W., Maasch, K. A., David Meeker, L., Meyerson, E. A., Gasse, F., van Kreveld, S., Holmgren, K., Lee-Thorp, J., Rosqvist, G., Rack, F., Staubwasser, M., Schneider, R. R., and Steig, E. J.: Holocene climate variability, Quaternary Res., 62, 243-255, 2004.

Mendes, I., Gonzalez, R., Dias, J. M. A., Lobo, F., and Martins, V.: Factors influencing recent benthic foraminifera distribution on the Guadiana shelf (Southwestern Iberia), Mar. Micropaleontol., 51, 171-192, 2004.

Milker, Y., Schmiedl, G., and Betzler, C.: Paleobathymetric history of the Western Mediterranean Sea shelf during the latest glacial period and the Holocene: Quantitative reconstructions based on foraminiferal transfer functions, Palaeogeogr. Palaeocl., 307, 324-338, 2011.

Mix, A. C., Bard, E., and Schneider, R.: Environmental processes of the ice age: land, oceans, glaciers (EPILOG), Quaternary Sci. Rev., 20, 627-657, 2001.

Mojtahid, M., Jorissen, F., Lansard, B., Fontanier, C., Bombled, B., and Rabouille, C.: Spatial distribution of live benthic foraminifera in the Rhône prodelta: Faunal response to a continental-marine organic matter gradient, Mar. Micropaleontol., 70, 177-200, 2009.

Murray, J. W.: Ecology and applications of benthic foraminifera, Cambridge University Press, Cambridge, 426 pp., 2006.

Myrow, P. M.: Bypass-zone tempestite facies model and proximality trends for an ancient muddy shoreline and shelf, J. Sediment. Petrol., 62, 99-115, 1992.

Myrow, P. M. and Southard, J. B.: Tempestite deposition, J. Sediment. Res., 66, 875-887, 1996.
Nittrouer, C. A., Kuehl, S. A., DeMaster, D. J., and Kowsmann, R. O.: The deltaic Nature of Amazon Shelf Sedimentation, Geol. Soc. Am. Bull., 97, 444-458, 1986.

Pérez-López, A. and Pérez-Valera, F.: Tempestite facies models for the epicontinental Triassic carbonates of the Betic Cordillera (southern Spain), Sedimentology, 59, 646-678, 2012.

Petschick, R.: MacDiff 4.2.2, available at: http://www.geol-pal. uni-frankfurt.de/Staff/Homepages/Petschick/classicsoftware. html (last access: 5 December 2016), 2000.

Peypouquet, J. P. and Nachite, D.: Les ostracodes en Méditerranée nord-occidentale, in: Ecologie des microorganismes en Méditerranée occidentale "ECOMED", edited by: Bizon, J. J. and Burollet, P. F., Association Française des Techniciens du Pétrole, Paris, 1984.

Pichard, G.: Les crues sur le bas-Rhône de 1500 à nos jours. Pour une histoire hydroclimatique, Méditerranée, 3-4, 105-116, 1995.

Pichard, G. and Roucaute, E.: Sept siècles d'histoire hydroclimatique du Rhône d'Orange à la mer (1300-2000), climat, crues, inondations, Méditerranée, no hors-série, 192, 2014.

Postma, G.: Sea-level-related architectural trends in coarse-grained delta complexes, Sediment. Geol., 98, 3-12, 1995.

Provansal, M., Vella, C., Arnaud-Fassetta, G., Sabatier, F., and Maillet, G.: Role of fluvial sediment inputs in the mobility of the Rhône delta coast (France), Géomorphologie, 4, 271-282, 2003.

Reimer, P. J., Bard, E., Bayliss, A., Beck, J. W., Blackwell, P. G., Bronk Ramsey, C., Buck, C. E., Cheng, H., Edwards, R. L., Friedrich, M., Grootes, P. M., Guilderson, T. P., Haflidason, H., Hajdas, I., Hatté, C., Heaton, T. J., Hoffmann, D. L., Hogg, A. G., Hughen, K. A., Kaiser, K. F., Kromer, B., Manning, S. W., Niu, M., Reimer, R. W., Richards, D. A., Scott, E. M., Southon, J. R., Staff, R. A., Turney, C. S. M., and van der Plicht, J.: IntCal13 and Marine13 Radiocarbon Age Calibration Curves 0-50,000 Years cal BP, Radiocarbon, 55, 1869-1887, 2013

Rey, T., Lefevre, D., and Vella, C.: Données nouvelles sur les lobes deltaïques du paléogolfe d'Aigues-Mortes à l'Holocène (Petite Camarhue, France), Quaternaire, 16, 329-338, 2005.

Roberts, N., Brayshaw, D., Kuzucuoğlu, C., Perez, R., and Sadori, L.: The mid-Holocene climatic transition in the Mediterranean: Causes and consequences, Holocene, 21, 3-13, 2011.

Rossi, V.: Ostracod assemblages from Holocene subsurface deposits of modern Po Delta: a palaeoenvironmental proxy record, Bolletino della Società Paleontologica Italiana, 48, 95-103, 2009.

Rossi, V. and Vaiani, S. C.: Benthic foraminiferal evidence of sediment supply changes and fluvial drainage reorganization in Holocene deposits of the Po Delta, Italy, Mar. Micropaleontol., 69, 106-118, 2008.

Ruiz, F., González-Regalado, M. L., and Muñoz, J. M.: Multivariate analysis applied to total and living fauna: seasonal ecology of recent benthic Ostracoda off the North Cádiz Gulf coast (southwestern Spain), Mar. Micropaleontol., 31, 183-203, 1997.

Seppä, H., Bjune, A. E., Telford, R. J., Birks, H. J. B., and Veski, S.: Last nine-thousand years of temperature variability in Northern Europe, Clim. Past, 5, 523-535, doi:10.5194/cp-5-523-2009, 2009.

Sgarrella, F. and Moncharmont Zei, M.: Benthic foraminifera of the Gulf of Naples (Italy): systematics and autoecology, Bollettino Società Paleontologica Italiana, 32, 145-264, 1993.

Shannon, C. E.: A mathematical theory of communication, Bell Syst. Tech. J., 27, 379-423, 1948. 
Sierro, F. J., Andersen, N., Bassetti, M. A., Berné, S., Canals, M., Curtis, J. H., Dennielou, B., Flores, J. A., Frigola, J., GonzalezMora, B., Grimalt, J. O., Hodell, D. A., Jouet, G., Pérez-Folgado, M., and Schneider, R.: Phase relationship between sea level and abrupt climate change, Quaternary Sci. Rev., 28, 2867-2881, 2009 .

Simonneau, A., Doyen, E., Chapron, E., Millet, L., Vannière, B., Di Giovanni, C., Bossard, N., Tachikawa, K., Bard, E., Albéric, P., Desmet, M., Roux, G., Lajeunesse, P., Berger, J. F., and Arnaud, F.: Holocene land-use evolution and associated soil erosion in the French Prealps inferred from Lake Paladru sediments and archaeological evidences, J. Archaeol. Sci., 40, 1636-1645, 2013.

Smith, D. E., Harrison, S., Firth, C. R., and Jordan, J. T.: The early Holocene sea level rise, Quaternary Sci. Rev., 30, 1846-1860, 2011

Stanford, J. D., Hemingway, R., Rohling, E. J., Challenor, P. G., Medina-Elizalde, M., and Lester, A. J.: Sea-level probability for the last deglaciation: A statistical analysis of far-field records, Global Planet. Change, 79, 193-203, 2011.

Stanley, D. J. and Warne, A. G.: Worldwide initiation of Holocene marine deltas by decceleration of sea-level rise, Science, 265 , 228-231, 1994.

Swindles, G. T., Plunkett, G., and Roe, H. M.: A delayed climatic response to solar forcing at $2800 \mathrm{cal}$. BP: multiproxy evidence from three Irish peatlands, Holocene, 17, 177-182, 2007.

Ta, T. K. O., Nguyen, V. L., Tateishi, M., Kobayashi, I., Tanabe, S., and Saito, Y.: Holocene delta evolution and sediment discharge of the Mekong River, southern Vietnam, Quaternary Sci. Rev., 21, 1807-1819, 2002.

Trincardi, F., Cattaneo, A., and Correggiari, A.: Mediterranean prodelta systems: natural evolution and human impact investigated by Eurodelta, Oceanography, 17, 34-45, 2004.

Van der Zwaan, G. J. and Jorissen, F.: Biofacial patterns in riverinduced shelf anoxia, Modern and Ancient Continental Shelf Anoxia: Geological Society, Special Publication, 58, 65-82, 1991.

Van Harten, D.: Use of ostracodes to recognize downslope contamination in paleobathymetry and a preliminary reappraisal of the paleodepth of the Prasás Marls (Pliocene), Crete, Greece, Geology, 14, 856-859, 1986.

Van Morkhoven, F. P. C. M.: Post-Palaeozoic Ostracoda. Their Morphology, Taxonomy, and Economic Use, Vol. 2, Generic descriptions, Elsevier Publishing, Amsterdam, 1963.

Vella, C.: Perception et évaluation de la mobilité du littoral holocène sur la marge orientale du delta du Rhône, PhD, UFR des Sciences géographiques et de l'amménagement, Aix-Marseille 1, Aix, 225 pp., 1999.

Vella, C., Fleury, T. J., Raccasi, G., Provansal, M., Sabatier, F., and Bourcier, M.: Evolution of the Rhone delta plain in the Holocene, Mar. Geol., 222-223, 235-265, 2005.

Vella, C., Fleury, T. J., Gensous, B., Labaune, C., and Tesson, M.: Holocene long-sequences and sedimentary discontinuities of the Rhône delta, Cahier de Géographie, 6, 159-170, 2008.
Walker, M. J. C., Berkelhammer, M., Björck, S., Cwynar, L. C., Fisher, D. A., Long, A. J., Lowe, J. J., Newnham, R. M., Rasmussen, S. O., and Weiss, H.: Formal subdivision of the Holocene Series/Epoch: a Discussion Paper by a Working Group of INTIMATE (Integration of ice-core, marine and terrestrial records) and the Subcommission on Quaternary Stratigraphy (International Commission on Stratigraphy), J. Quaternary Sci., 27, 649-659, 2012.

Wanner, H., Beer, J., Bütikofer, J., Crowley, T. J., Cubasch, U., Flückiger, J., Goosse, H., Grosjean, M., Joos, F., Kaplan, J. O., Küttel, M., Müller, S. A., Prentice, I. C., Solomina, O., Stocker, T. F., Tarasov, P., Wagner, M., and Widmann, M.: Mid- to Late Holocene climate change: an overview, Quaternary Sci. Rev., 27, 1791-1828, 2008.

Wanner, H., Solomina, O., Grosjean, M., Ritz, S. P., and Jetel, M.: Structure and origin of Holocene cold events, Quaternary Sci. Rev., 30, 3109-3123, 2011.

Wanner, H., Mercolli, L., Grosjean, M., and Ritz, S. P.: Holocene climate variability and change; a data-based review, J. Geol. Soc., 172, 254-263, doi:10.1144/jgs2013-101, 2014.

Wassenburg, J. A., Immenhauser, A., Richter, D. K., Niedermayr, A., Riechelmann, S., Fietzke, D., Scholz, D., Jochum, K. P., Fohlmeister, J., Schröder-Ritzrau, A., Sabaoui, A., Riechelmann, D. F. C., Schneider, L., and Esper, J.: Moroccan speleothem and tree ring records suggest a variable positive state of the North Atlantic Oscillation during the Medieval Warm Period, Earth Planet. Sc. Lett., 375, 291-302, 2013.

Weiss, B.: The decline of Late Bronze Age civilization as a possible response to climatic change, Climatic Change, 4, 173-198, 1982.

Wilhelm, B., Vogel, H., Crouzet, C., Etienne, D., and Anselmetti, F. S.: Frequency and intensity of palaeofloods at the interface of Atlantic and Mediterranean climate domains, Clim. Past, 12, 299-316, doi:10.5194/cp-12-299-2016, 2016.

Xue, Z., Liu, J. P., DeMaster, D., Van Nguyen, L., and Ta, T. K. O.: Late Holocene Evolution of the Mekong Subaqueous Delta, Southern Vietnam, Mar. Geol., 269, 46-60, 2010.

Yamaguchi, T. and Norris, R. D.: Deep-sea ostracode turnovers through the Paleocene-Eocene thermal maximum in DSDP Site 401, Bay of Biscay, North Atlantic, Mar. Micropaleontol., 86-87, 32-44, 2012.

Zaïbi, C., Carbonel, P., Kamoun, F., Fontugne, M., Azri, C., Jedoui, Y., and Montacer, M.: Evolution of the sebkha Dreîaa (SouthEastern Tunisia, Gulf of Gabes) during the Late Holocene: Response of ostracod assemblages, Revue de Micropaléontologie, 55, 83-97, 2012.

Zhou, B. and Zhao, Q.: Allochthonous ostracods in the South China Sea and their significance in indicating downslope sediment contamination, Mar. Geol., 156, 187-195, 1999. 